Board of Governors of the Federal Reserve System

International Finance Discussion Papers

Number 738

September 2002

Exchange Rate Regimes and Financial Dollarization:

Does Flexibility Reduce Bank Currency Mismatches?

Carlos Ó. Arteta

NOTE: International Finance Discussion Papers are preliminary materials circulated to stimulate discussion and critical comment. References in publications to International Finance Discussion Papers (other than an acknowledgment that the writer has had access to unpublished material) should be cleared with the author or authors. Recent IFDPs are available on the Web at www.federalreserve.gov/pubs/ifdp/. 


\title{
Exchange Rate Regimes and Financial Dollarization: Does Flexibility Reduce Bank Currency Mismatches?
}

\author{
Carlos Ó. Arteta*
}

Abstract: The dollarization of bank deposits and credit is widespread in developing countries, resulting in varying degrees of currency mismatches in domestic financial intermediation, which in turn might accentuate bank balance sheet fragility. It is widely argued that flexible exchange rate regimes encourage banks to match dollar-denominated liabilities with a corresponding amount of dollar-denominated assets, ameliorating currency mismatches. Does the behavior of dollar deposits and credit in financially dollarized economies support that presumption? A new database on deposit and credit dollarization in developing and transition countries is assembled and used to address this question. Empirical results suggest that, if anything, floating regimes seem to exacerbate, rather than ameliorate, currency mismatches in domestic financial intermediation, as those regimes seem to encourage deposit dollarization more strongly than they encourage matching via credit dollarization.

Keywords: dollarization, exchange rate, regimes, currency mismatches, banks JEL Classification Number: F33, G21

\footnotetext{
* Economist, Division of International Finance, Mail Stop 24, Federal Reserve Board, Washington, DC 20551. Telephone: 202-452-2762. Fax: 202-736-5638. E-mail: carlos.o.arteta@frb.gov. I am highly indebted to Barry Eichengreen, David Romer, and Andrew Rose for their comments and guidance. I also thank Roger Craine, Julian di Giovanni, Jon Faust, Steven Kamin, Edward Miguel, Marc Muendler, Maurice Obstfeld, John Rogers, Nathan Sheets and seminar participants at UC Berkeley, the Federal Reserve Board, the Federal Reserve Bank of Boston, and the U.S. Department of the Treasury for helpful comments and suggestions; Enrica Detragiache and Miguel Savastano for help during the early part of this project; and Virgilio Sandoval and Holger Wolf for sharing their exchange rate regime data. I gratefully acknowledge financial support from the Graduate Division, the Institute of Business and Economic Research, and the Institute of International Studies of UC Berkeley. All remaining errors are my own. The views in this paper are solely the responsibility of the author and should not be interpreted as reflecting the views of the Board of Governors of the Federal Reserve System or of any other person associated with the Federal Reserve System.
} 


\section{Introduction}

Partial dollarization, defined as the holding by residents of a significant share of their assets and liabilities in the form of foreign-currency-denominated instruments, is widespread in many developing and transition economies. ${ }^{1}$ Financial intermediation in particular has become heavily dollarized in several countries. This process of financial dollarization has been reflected in varying patterns of dollarization of bank deposits and loans, which in turn have influenced the extent of currency mismatches in financial intermediation.

In general, the currency mismatches of banks and firms, and the resulting foreign currency exposure, are seen as a source of financial fragility. One of the debates about the causes of those mismatches relates to the exchange rate regime. There are two views on the links between regimes and mismatches - in particular, on the question of whether greater flexibility encourages hedging. The majority view (e.g. Burnside et al. 2000, Mishkin 1996, Obstfeld 1998, Goldstein 2002) would appear to be that fixed exchange rates encourage currency mismatches because banks and firms do not hedge their dollar liabilities: they overlook the need to limit their open foreign currency positions, since they believe themselves to be immune to exchange rate fluctuations given the commitment from the authorities to defend the peg. Therefore, the argument goes, floating exchange rates would encourage banks and firms to match dollar liabilities with a corresponding quantity of dollar assets, as they seek to limit their exposure to exchange risk. An exchange rate that fluctuates more freely would constantly remind banks and firms of the importance of limiting their unhedged dollar liabilities.

On the other hand, there is a notable minority view (e.g. Eichengreen and Hausmann 1999, McKinnon 2001), which argues that greater flexibility increases the cost of hedging and therefore may not lead to lower currency mismatches. This view emphasizes that the cost of insurance against exchange risk goes up with exchange rate volatility. Insofar as floating regimes lead to greater volatility, therefore, they may raise the cost of insurance and result in less hedging, rather than more.

\footnotetext{
${ }^{1}$ Following the usual vocabulary, this paper employs the terms "dollar" when referring to any foreign currency and "peso" when referring to any domestic currency. In addition, the term "dollarization" in this paper does not refer to the adoption of a foreign currency as legal tender ("full dollarization").
} 
In the context of dollarized banking systems, this debate centers more prominently on the currency composition of deposits and credits. A potential implication of the majority view would be that floating regimes would encourage banks to match dollar deposits with dollar loans. Note, however, that greater exchange rate flexibility also enhances the attractiveness of dollar deposits as households seek to insure themselves against currency risk. Whether banks can and will respond to this further increase in dollar deposits by further increasing dollar loans is an open question. Substituting foreign-currency-denominated loans for domestic-currencydenominated loans trades one source of risk (default risk, reflecting the fact that sudden depreciations leave some firms unable to repay) for another (currency risk). That is, the cost of dollar credit as insurance against currency risk is greater default risk. Banks may have good reasons to regard it as undesirable to move too far to one or the other extreme of this tradeoff. Flexible exchange rates thus may encourage deposit dollarization more strongly than they encourage credit dollarization. Currency mismatches between deposits and loans may therefore be greater, not lower, under floating regimes. For all these reasons, the overall effect of greater exchange rate flexibility on credit and deposit dollarization, and thus on currency mismatches in financial intermediation, is an empirical question.

In most developing economies, credits and deposits account for a significant portion of total bank assets and liabilities. Therefore, currency mismatches in financial intermediation may greatly shape the overall foreign currency exposure of dollarized banking systems. However, despite the obvious relevance of the topic, there has been little theoretical work and no systematic, cross-country empirical work on the determinants of the currency composition of bank assets and liabilities in dollarized countries. While the dollarization of deposits has been extensively studied in the context of currency substitution, the dollarization of bank loan portfolios has received scant theoretical attention and no systematic empirical analysis, even though deposit and credit dollarization are the two sides of the same (dollar) coin. Moreover, there does not appear to be a single systematic empirical study, as far as I am aware, on the links between the exchange rate and bank currency mismatches in dollarized economies or elsewhere in the developing world. This paper is the first cross-country, large- $n$ empirical work on these issues.

To analyze the effects of exchange rate regimes on financial dollarization and currency mismatches in financial intermediation, I assemble the first comprehensive database on 
dollarization. Its first component is data on dollar-denominated bank credit and deposits in a large number of developing and transition economies for the past two decades. Its second component is information on bank regulations in the same sample of dollarized countries. Using these data, I study the impact of the exchange rate regime on credit dollarization, deposit dollarization, and deposit-credit currency mismatches, explicitly controlling for the institutional and regulatory framework. I use alternative variable definitions, different estimation procedures, a battery of sensitivity tests, and deal with potential endogeneity.

I find little support for the view that flexible exchange rate regimes reduce currency mismatches in domestic financial intermediation. If anything, the opposite seems to be true. Deposit dollarization is significantly greater under floating regimes, while credit dollarization does not appear to differ significantly across regimes. Since exchange rate flexibility encourages deposit dollarization much more strongly than it encourages credit dollarization, floating exchange rates result in greater deposit-credit mismatches. These results hold across different variable definitions, estimation methods, and robustness checks. ${ }^{2}$

Insofar as currency mismatches in financial intermediation can significantly influence the overall foreign currency exposure of banking systems in dollarized economies, these results, if correct, cast doubt on the widely believed presumption that floating regimes unambiguously alleviate such exposures. And if overall currency mismatches indeed undermine financial stability, then these results suggest that greater exchange rate flexibility, by itself, may not necessarily lead to safer and sounder financial systems in developing countries, which would have important implications for exchange rate and financial policy.

The remainder of this paper is organized as follows. Section 2 outlines the methodology and introduces the new dollarization database and other data used. Section 4 presents empirical evidence on the impact of exchange rate regimes on dollarization and on currency mismatches in financial intermediation. Section 5 discusses the implications of the results as well as some caveats. Section 6 concludes.

\footnotetext{
2 Before proceeding, an important caveat is in order. This paper focuses on the effects of exchange rate regimes on currency mismatch in domestic financial intermediation. A complete assessment of the impact of regimes on overall bank currency mismatches is not the main focus of this paper, as it would require additional data on the currency denomination of other components of bank balance sheets and on
} 


\section{Methodology and Data}

\subsection{Methodology}

The ultimate goal of this paper is to test the presumption that, compared to fixed regimes, floating regimes lead to higher credit dollarization vis-à-vis deposit dollarization, thus reducing currency mismatches in financial intermediation. To that end, I estimate the following relationship:

$$
\text { Dollarization }=\beta_{0}+\beta_{1} \text { Intermediate }_{i t}+\beta_{2} \text { Floating }_{i t}+\gamma^{\prime} \text { Controls }_{i t}+\varepsilon_{i t}
$$

Dollarization stands for a measure of either credit or deposit dollarization, or for the corresponding deposit-credit mismatch. Intermediate and Floating stand for two binary indicators for whether country $i$ has an intermediate or a floating regime in place at time $t$, the reference group being fixed regimes. The term Controls represents a vector of other explanatory variables affecting dollarization. This vector includes a set of macroeconomic, regulatory, and historical variables, to be detailed later. Finally, $\varepsilon$ is a disturbance term. The coefficient of interest is $\beta_{2}$.

I begin the empirics with graphical event-study analysis, to study the behavior of dollarization and mismatches before and after the adoption of floating exchange rate regimes. Thereafter, I concentrate in "tranquil" periods (i.e. periods when there were no regime changes) and use three multivariate estimation procedures. First, I compute the benchmark results via pooled OLS regressions to assess the cross-regime behavior of dollarization and mismatches. Second, I estimate panel data regressions to exploit the time dimension of the data and to account for country-specific effects. Finally, I use instrumental variables to control for the potential endogeneity of the exchange rate regime. To check for the robustness of the results, I use alternative definitions of dollarization and exchange rate regimes and conduct various sensitivity tests throughout the paper.

hedging in insurance markets against currency risk. These data are unfortunately scarce. I do touch on those issues, but in a more limited way, as detailed below. I elaborate on this and other caveats below. 


\subsection{Dollarization Data}

The unbalanced panel data set assembled for purposes of this paper consists of monthly observations, mainly from the early 1990s to 2000. Data on the aggregate volume of deposit money banks' foreign-currency-denominated ("dollar") deposits of residents are available for 92 developing and transition economies. Data on the aggregate volume of deposit money banks' foreign-currency-denominated ("dollar") credit to the resident private sector are available for 40 developing and transition economies, almost all of which also have dollar deposits data. The time span varies across countries, with some having data from as early as 1975 and some having data only from about 1995 onwards. ${ }^{3}$ The main sources are data used by the IMF in constructing its International Financial Statistics, complemented by printed Central Bank bulletins from the monetary authorities of several countries. Appendix A presents more detailed information on country sample, data definitions, availability, and sources. These data allow for the construction of currency mismatch measures for 37 countries. This sample of countries covers all regions of the world.

While the dollarization data are available at a monthly frequency, several explanatory variables are not (e.g. World Bank macroeconomic data, regulatory data, or exchange rate regimes, detailed below). I therefore convert the dollarization data to annual frequency in the empirical analysis below. As a result, the annualized data end in 1999 or, in a few cases, the year 2000.4

I define dollarization in two ways. The first definition emphasizes the behavior of credit and deposit dollarization and scales dollar credit and deposits by total bank credit and deposits, respectively. The second definition provides a sense of the magnitude of credit and deposit dollarization and scales dollar credit and deposits by total bank assets and liabilities, respectively. The first definition focuses on portfolio allocation decisions, while the second

\footnotetext{
${ }^{3}$ Frequent changes in the format of primary sources are a major reason for the diverse time coverage.

4 Finally, there are a few instances in which values for dollar credit or deposits are equal to zero, principally when the data come from electronic sources. Unfortunately, it is not clear whether this means that the actual value was zero (e.g. values for dollar credit were zero because dollar credit was prohibited) or whether the data were missing. Therefore, I only work with strictly positive values of the relevant variables, and set any zero value to missing.
} 
focuses on the relative importance of the financial dollarization process. ${ }^{5}$ Given these considerations, the dollarization ratios constructed are:

- Credit dollarization ratio. This is measured as: a) the ratio of dollar credit to the private sector over total credit to the private sector; or as b) the ratio of dollar credit to the private sector over total bank assets.

- Deposit dollarization ratio. This is measured as: a) the ratio of dollar deposits over total deposits; or as b) the ratio of dollar deposits over total bank liabilities.

- Deposit-credit mismatch ratio. This is measured as the difference between dollar deposits and dollar credit divided by total bank liabilities.

Appendix B displays the dollarization series for a subset of countries in the sample that have data on both dollar credit and deposits. ${ }^{6}$

Some data limitations should be noted. Although private credit and deposits represent the bulk of domestic assets and liabilities, as well as an important component of total assets and liabilities, the analysis would greatly benefit from the inclusion of data on other components of bank balance sheets, as well as off-balance-sheet transactions in hedging markets. ${ }^{7}$ In addition, data on domestic- and foreign-currency lending and deposit interest rates are important in assessing the role of interest rate differentials for financial dollarization. These data are unfortunately scarce.

\footnotetext{
${ }^{5}$ As it is shown below, it turns out that the use of both definitions of dollarization yields very similar results.

${ }^{6}$ Each figure in Appendix B consists of two parts. The top part shows the series scaled by total credit and deposits, while the bottom part shows the series scaled by total assets and liabilities. Credit dollarization is denoted by circles and deposit dollarization is denoted by a continuous line. All values are percentages. Figure B1 shows the dollarization patterns for non-floating countries (countries under fixed or intermediate regimes for the whole period for which they have data for both dollar credit and deposits); Figure B2 shows the series for floating countries; and Figure B3 shows the series for countries that experienced both non-floating and floating regimes at one point or another in the sample period. Monthly data are used, and sample periods and scales vary by panel.

${ }^{7}$ In particular, it would be useful to have data on foreign assets and liabilities in dollars, as banks could have open dollar positions with non-residents to finance dollar lending to domestic firms, or could match dollar deposits with liquid dollar assets held abroad. The focus of this paper on dollarization and mismatches in domestic financial intermediation ameliorates these limitations.
} 


\subsection{Regulatory Arrangements Data}

Analyzing the determinants of dollarization requires controlling for the institutional and regulatory arrangements under which banking takes place. For instance, several dollarized economies temporarily restricted dollar deposits and/or credit heavily. ${ }^{8}$ Insofar as those restrictions were usually accompanied by pegged rates, one could mistakenly attribute a low level of dollarization to the fixed regime. Similarly, regulations may freely allow dollar deposits but restrict dollar credit, thus creating a mismatch that has little to do with banks' optimizing behavior. Moreover, some countries restrict dollar deposits or credit to some sectors (e.g. residents that earn foreign exchange from abroad), thus affecting the pattern of financial dollarization above and beyond the true impact of the exchange rate regime. And the fact that the regulatory framework can be time-varying renders econometric techniques such as fixed effects unable to fully control for it. ${ }^{9}$ Strikingly, almost all previous research on partial dollarization fails to control for the regulatory environment. ${ }^{10}$

To my knowledge, there is no source of comprehensive regulatory information on financial dollarization to date. The most comprehensive database on bank regulation and supervision currently available, compiled by Barth, Caprio, and Levine (2001), says nothing about dollarization or currency mismatch regulations. To overcome these data limitations, I gathered qualitative information on the regulatory arrangements of dollarization from various issues of the IMF Annual Report on Exchange Arrangements and Exchange Restrictions and other IMF publications. The information collected allows for the construction of two binary indicators:

- Whether a country allows residents' dollar deposit accounts freely or with minor conditions, as opposed to severely restricting them, limiting them to certain residents (e.g. individuals or firms that earn foreign exchange), or prohibiting them.

\footnotetext{
${ }^{8}$ Bolivia, Mexico, and Peru during the 1980s are the best-known examples.

9 For instance, Appendix Figure B3 shows that the restrictions in the use of dollar instruments for financial intermediation in Peru between 1985 and 1990 had a major but temporary impact on dollarization.

10 Savastano $(1992,1996)$ is a notable exception.
} 
- Whether a country allows dollar lending freely or with minor conditions, as opposed to severely restricting them, limiting them to certain residents (e.g. individuals or firms that earn foreign exchange), or prohibiting them.

Finally, I attempted to create a third binary indicator - whether or not a country has specific limitations on banks' open foreign currency positions. While qualitative information suggests that such limitations are common, it was not possible to map that information into a standard binary variable, due to heterogeneous definitions and different regulations in each country. ${ }^{11}$

\subsection{Exchange Rate Regime Data}

I employ the standard exchange rate regime classification widely used in the empirical literature and based on the regime reported by monetary authorities to the IMF and published in the IMF Annual Report on Exchange Arrangements and Exchange Restrictions. In general, this classification distinguishes regimes as fixed (single pegs or basket pegs), intermediate (limited flexibility, cooperative arrangements, crawling pegs or bands, or managed floats following a predetermined set of indicators), and floating (managed floats with no pre-announced path for the exchange rate or independent floats). However, the regime that countries claim to operate may be different from the regime actually followed: many self-described floaters continuously try to minimize exchange rate volatility, and some pegged regimes frequently readjust their parity. The patterns of dollarization may differ depending upon whether or not a country's authorities act accordingly to the reported regime. To address these inconsistencies, I revised and corrected this classification to account for coding errors, and I reconciled this de jure information with a new de facto IMF classification (available only from 1999 onwards) that distinguishes between managed floats and de facto pegs under managed floating. ${ }^{12}$ These data are available at an annual frequency. ${ }^{13}$

11 This is clearly an issue that deserves further research.

12 I thank Virgilio Sandoval for kindly providing the new de facto IMF regime data.

${ }^{13}$ To further correct errors with the de jure IMF data and make it as close to actual exchange rate behavior as possible, I also reviewed data on frequent and infrequent parity adjusters, first used in Ghosh et al. (1997), available until 1996. I thank Holger Wolf for kindly providing these data. 
To assess the robustness of the results to the exchange rate regime classification used, I also estimate (but do not report) the regressions below using the annual regime data constructed by Levy-Yeyati and Sturzenegger (LYS 2000) as an alternative classification. The LYS classification is based on cluster analysis and takes into account actual exchange rate volatility, the volatility of exchange rate changes, and the volatility of reserves. ${ }^{14} \mathrm{I}$ indicate below whether the results are sensitive to the regime classification used. ${ }^{15}$

Other explanatory variables come from standard sources, such as the International Financial Statistics of the IMF and the World Development Indicators of the World Bank. Such variables include inflation, nominal exchange rates, trade openness, interest rates, terms of trade, land area, etc., as detailed below.

\section{Empirical Analysis}

\subsection{Event-Study Analysis}

To study the differences in the behavior of dollarization and mismatches before and after regime changes, I undertake event-study analysis. Figure 1 compares the average values of the dollarization series around the time of floating rate regime adoptions with the average values of the series for countries under fixed or intermediate regimes that never adopted flexibility. The top part uses the series scaled by total credit/deposits, while the bottom part uses the series scaled by total assets/liabilities. The panels show the pattern of deposit and credit dollarization and mismatches two years before and after floating regime adoptions (that is, changes from either fixed to floating or from intermediate to floating regimes). ${ }^{16}$ Time is measured in the horizontal axis (from -2 to +2 years around regime changes). In each panel, the vertical line is

\footnotetext{
14 Note, however, that LYS do not use interest rate data in their analysis, which represents a major limitation, as interest rates can be extensively used to fix and defend the exchange rate. In addition, they classify countries as fixers if they exhibit low exchange rate variability but high reserve volatility, but do not account for the presence of capital controls, which may minimize the need of using reserves to manage the peg. Finally, this classification is available for significantly fewer observations in my sample. ${ }^{15}$ All unreported results mentioned below are available upon request.

${ }^{16}$ I do not consider the case of changes from flexible to non-flexible regimes, as those events were rare in my sample period, and because they are not relevant for the purpose of testing the impact of floating regimes adoptions on dollarization.
} 
the time of the regime change, and the horizontal line is the average value of the relevant dollarization series for the non-floating observations. The average values of the dollarization series during regime changes are surrounded by two-standard-error bands. Annualized data are used.

Figure 1 shows that deposit dollarization significantly increases after the adoption of a flexible regime. Credit dollarization also goes up, but not significantly. As a result, the depositcredit mismatch rises significantly as well. This is the first evidence that floating regimes do not yield greater credit dollarization vis-à-vis deposit dollarization. Currency mismatches in financial intermediation seem to go up, not down, in other words, during the first years after the adoption of floating regimes. ${ }^{17}$

\subsection{Descriptive Statistics}

The previous event-study analysis focused on the periods around floating regime adoptions. In order to focus on "tranquil" periods (i.e. periods in which no regime changes took place), I henceforth use a two-sided, one-year exclusion window around regime changes that led to the adoption of a floating regime. This exclusion window helps avoid potential regime "contamination" which may occur before and particularly after the collapse of a fixed regime. If residents expect the collapse of a peg and a large devaluation, they may reduce their holding of peso assets in advance. More importantly, the collapse of the peg may generate of burst of dollarization (particularly deposit dollarization), which can be mistakenly regarded as being caused by the subsequent flexible regimes.

Table 1 reports descriptive statistics of deposit and credit dollarization and currency mismatches across regimes. Clearly, dollarization and mismatches are significantly higher under floating than under fixed regimes. Under flexible regimes, credit dollarization is about twice as much as under fixed regimes, while deposit dollarization is nearly three times as much.

\footnotetext{
17 I also use the LYS classification in an analogous event study (not reported). The patterns appear to be different. Compared to the average value in the non-floating observations, deposit dollarization is higher before a regime change, and continues to be higher after such change. However, credit dollarization is not significantly different from its non-floating average before or after the adoption of a floating regime, nor is the degree of currency mismatch. Although one cannot say that the mismatch increases after the adoption of a LYS floating regime, one can safely state that they do not decline, contrary to the implications of the majority view.
} 
Mismatches, which are virtually equal to zero under fixed regimes, are about 6 per cent of total liabilities under floating regimes. These patterns hold regardless of the denominators used to scale dollar credit and deposits. 18

Similar information is conveyed in Table 2. This table reports a basic version of equation $(1)$, in the form of the pooled OLS regression:

$$
\text { Dollarization }=\beta_{0}+\beta_{1} \text { Intermediate }_{i t}+\beta_{2} \text { Floating }_{i t}+\varepsilon_{i t}
$$

Here, $\beta_{0}$ is the mean of the relevant dollarization ratio under fixed regimes (the reference group), while $\beta_{0}+\beta_{1}$ and $\beta_{0}+\beta_{2}$ are the means under intermediate and flexible regimes, respectively. ${ }^{19}$

Both credit and deposit dollarization are significantly higher in floating regimes, in the economic and statistical senses. When scaling by total credit and deposits, credit dollarization is 15 per cent higher under floating regimes than under fixed exchange rates (t-statistic: 4.3), and deposit dollarization is 25 per cent higher (t-statistic: 14.5). When scaling by total assets and liabilities, the numbers are 7 per cent (t-statistic: 3.9) and 11 per cent (t-statistic: 12.3), respectively. As a result, deposit-credit mismatches are also higher: while such mismatches are not statistically different from zero under fixed regimes, they are about 6 per cent of total bank liabilities under floating regimes (t-statistic: 4.5). This goes against the presumption that floating regimes are associated with lower currency mismatch in financial intermediation. ${ }^{20}$

\footnotetext{
18 When using the LYS regime data, dollarization and mismatches are also lowest under fixed regimes, but they are highest under intermediate rather than under flexible regimes. However, the number of usable observations under LYS floats is much smaller than the number of usable observations under IMF floats, due mainly to the exclusion windows used throughout the paper.

19 For consistency with subsequent regression analysis, I estimate this equation using heteroskedasticityrobust standard errors.

20 A slightly different picture emerges when using the LYS regimes. Unreported results using this alternative classification suggest that credit dollarization appears to be no different in fixed or flexible regimes. On the other hand, deposit dollarization as a share of total deposits is about 12 per cent higher under flexible regimes (t-statistic: 3.7); as a share of total liabilities, it is about 6 per cent higher (t-statistic: 3.5). However, currency mismatches do not clearly differ across regimes. Similar results obtain when conducting additional multivariate estimations (analogous to those discussed below).
} 


\subsection{Benchmark Results}

I now proceed to estimate an extended version of equation (1), in the form of the pooled OLS regression with heteroskedasticity-robust standard errors: ${ }^{21}$

$$
\begin{aligned}
\text { Dollarization }= & \beta_{0}+\beta_{1} \text { Intermediate }_{i t}+\beta_{2} \text { Floating }_{i t}+ \\
& \gamma_{1}^{\prime} \text { MacroControls }_{i t}+\gamma_{2}^{\prime} \text { HistoricalControls }_{i t}+\gamma_{3}^{\prime} \text { Re gulatory Controls }_{i t}+\varepsilon_{i t}
\end{aligned}
$$

The macroeconomic controls come from the existing literature on partial dollarization and include the following:

- Interest rate differential. One of the potential determinants of dollarization are lending and deposit interest rate differentials. I use the difference of the country's money market rate with respect to the rate in the United States as a proxy.

- $\quad T r a d e / G D P$. It can be argued that trade dependence encourages dollarization, as relatively large export and import sectors may require dollar accounts for their transactions. On the other hand, foreign exchange earnings of exporters may reduce the need for dollar credit from resident banks. The ratio of trade (exports plus imports) to GDP is used to control for openness.

- Inflation. Inflation has been a key determinant of dollarization in many countries. It is also a good proxy for the macroeconomic mismanagement that may fuel dollarization. ${ }^{22}$

- Depreciation. Large and sudden downward movements of the exchange rate have also exacerbated nominal instability and thus dollarization. This variable also serves to control for potential valuation effects. ${ }^{23}$

- Time trend. As the movement towards floating regimes has accelerated in the past ten years, so has dollarization. To distinguish the impact of floating regimes on dollarization from a common trend, I add a time trend. ${ }^{24}$

${ }^{21}$ Appendix A presents more detailed information about the controls used.

22 In addition, there is some evidence (Ghosh et al. 1997) suggesting that inflation is higher under floating regimes, so its inclusion avoids potential omitted-variable problems.

${ }^{23}$ Valuation effects may be present regardless of the currency used to express the values of the variables. In particular, any dollarization ratio will increase after depreciation by construction. If all volumes are expressed in their peso value, the ratio's numerator will increase, but only one part of its denominator (the dollar component) will. On the other hand, if all volumes are expressed in their dollar values, its numerator will stay constant, but its denominator will go down (as the dollar value of the denominator's peso component decreases). 
Financial dollarization appears to be persistent. The set of historical variables used to control for hysteresis and persistence effects includes:

- Maximum historical rate of inflation. High inflation or hyperinflation at one point in the past may have led to the acceleration of dollarization in many countries. Even if low inflation is achieved later, hysteresis effects may persist. ${ }^{25}$ Including the highest past rate of inflation controls for these effects. I define the maximum historical rate of inflation as the "running" maximum: if in a given year a new maximum is reached, it replaces the previous one, until a higher rate of inflation is achieved in a subsequent year. ${ }^{26}$

- Maximum historical rate of depreciation. The definition of this variable is analogous to that of the maximum historical inflation above.

Finally, the set of regulatory variables affecting dollarization includes the two binary indicators mentioned previously:

- Foreign currency loans allowed. This indicator explicitly controls for whether dollar credit can be freely issued.

- Foreign currency deposits allowed. Similarly, this indicator explicitly controls for whether dollar deposits can be freely issued.

Table 3 reports results scaling the dollarization series by total credit and deposits, and Table 4 reports results scaling the dollarization series by total assets and liabilities. Table 5 reports estimations for the deposit-credit currency mismatch variable. In each table, I use a variety of specifications to assess the robustness of the results. More specifically, each of Tables 3 and 4 reports eight columns, which contain four pairs of specifications. Each pair consists of one regression for credit dollarization and an analogous regression for deposit dollarization. Table 5 uses the same four specifications in the mismatch regressions. ${ }^{27}$

${ }^{24}$ Given collinearity among some controls - particularly inflation and depreciation - I include them alternatively in different specifications, as shown below. However, including them together did not change the results for the coefficients of interest.

${ }^{25}$ Examples of this phenomenon are Argentina (before 2002), Bolivia, Nicaragua, and Peru.

${ }^{26}$ Note that this definition may result in a time-invariant maximum inflation for many countries, as the highest level of inflation usually took place in the 1980s in many cases, while dollarization data are usually available from the early 1990s onwards.

${ }^{27}$ Note that deposit dollarization regressions cover a larger number of countries and, as a result, include more observations than credit dollarization regressions. Fixing the number of observations to a common sample for deposits and credits does not change the results - indeed, this is exactly what the regressions for the currency mismatch variable (which is constructed using deposit and credit data) show. 
Contrary to the implications of the majority view, Tables 4 and 5 report some evidence that credit dollarization is lower under floating regimes. The point estimate for the floating regime coefficient is always negative, but it is significant only in half of the credit dollarization regressions. On the other hand, there is overwhelming evidence that deposit dollarization is significantly higher under floating regimes: Table 4 suggests that the ratio of dollar deposits to total deposits is about 10 to 12 per cent higher, while Table 5 indicates that the ratio of dollar deposits to total liabilities is 6 to 7 per cent higher under flexible exchange rates. ${ }^{28}$ All these coefficients are significant at the 99 per cent confidence level. And the fact that the results reported in Table 4 are qualitatively similar to those reported in Table 5 suggests that they are insensitive to scaling. ${ }^{29}$

More importantly, Table 6 shows that floating regimes are consistently associated with greater, not lower, mismatches. This effect is economically large and statistically significant in all regressions: as a share of total bank liabilities, currency mismatches are 7 to 8 per cent higher under exchange rate flexibility.

The performances of current inflation and depreciation are relatively poor. On the other hand, maximum inflation and depreciation have a significant explanatory power in both deposit and credit dollarization regressions, even more than their contemporaneous counterparts, underlining the importance of past events in shaping current dollarization. Their coefficients are positive and generally significant: countries that suffered high inflation or experienced large depreciation in the past are more prone to have large dollarization of both credit and deposits in the present.

The time trend confirms the presumption that both deposit and credit dollarization have increased over time; on the other hand, it would appear that mismatches have declined. Furthermore, the regulatory indicators have a very large explanatory power, confirming the importance of the institutional framework in the dollarization process. The performance of interest rate differentials is poor. Finally, the results for trade openness suggest a negative link

28 The intermediate regime category exhibits qualitatively similar patterns.

${ }^{29}$ Unreported results using the LYS classification suggest that credit dollarization is significantly and consistency lower under floating. Deposit dollarization is higher under floating regimes, but the coefficient is not statistically significant in several specifications. Finally, there is some evidence that currency mismatches are higher under LYS floating regimes, but it is not robust. 
with dollarization; perhaps residents in relatively closed economies need to rely more on banksupplied foreign exchange.

In sum, the evidence strongly suggests that floating exchange rate regimes do not lead to greater credit dollarization, while they result in significantly higher deposit dollarization. As a consequence, currency mismatches in financial intermediation are greater under floating regimes. ${ }^{30}$

\subsection{Robustness Tests}

To assess the robustness of these findings, I conducted extensive sensitivity analysis, which I do not report to save space.

Deposit insurance. The presence of deposit insurance may reduce depositors' incentives to withdraw their funds in periods of banking turmoil. Insofar as deposit insurance is part of the existing financial safety net, it may also affect banks' incentives and the pattern of loan dollarization. Including a binary annual indicator (constructed by Demirgüç-Kunt and Detragiache 2000) for the presence of an explicit deposit insurance scheme that covers dollar accounts suggests that mismatches are lower under such schemes. However, the channel for this effect is not clear: neither credit nor deposit dollarization seems to be different under deposit insurance. In any event, the key result still holds: deposit-credit currency mismatches are larger under floating exchange rates.

Forward markets. The presence of an insurance market against exchange risk may influence banks' behavior regarding mismatches and open currency positions. Although data on the volume of hedging activities by banks in insurance markets are not available, I constructed an indicator for the existence of a forward exchange market, based on information from the country pages of the IMF Annual Reports for the past two decades. ${ }^{31}$ The relevant results are insensitive to its inclusion: floating regimes are still associated with greater deposit dollarization and larger currency mismatches. In addition, it seems as if the presence of a forward market

\footnotetext{
${ }^{30}$ I also estimated the regressions with standard errors that are robust to country clustering, thus relaxing the assumption of within-country independence. The results are less well defined, but the evidence that deposit dollarization is higher under floating regimes still holds unscathed.

31 This dummy takes the value of one if a forward market was reported to exist, and zero if such market was reported to be underdeveloped, heavily regulated, or nonexistent.
} 
tends to reduce dollarization and mismatches. Perhaps the availability of insurance against currency risk reduces the need for banks and depositors to dollarize their assets: they might prefer to hedge their exposures in the form of forward contracts instead of in the form of dollar loans and deposits.

Managed vs. independent floats. The IMF floating group includes managed floats without a predetermined path for the exchange rate as well as independent floats. Are the results being driven by one of the components of the IMF "float" dummy? To answer this question, I disaggregate the floating dummy into its two subcomponents and include them concurrently. Interestingly, both kinds of floats - managed and independent - are associated with larger mismatches. And there is some evidence that managed floats increase credit dollarization, while independent floats reduce it.

Additional sensitivity analysis. I undertook other robustness tests, estimating permutations to the benchmark specifications. Those permutations included:

- Using a two-year exclusion window instead of the one-year window.

- Changing the definition of credit dollarization and currency mismatches by including bank credit to other sectors of the economy (when such data were available). ${ }^{32}$

- $\quad$ Dropping outliers and excluding countries with implausibly low or high mismatch (e.g. countries where credit dollarization was extremely low while deposit dollarization was very large). ${ }^{33}$

- $\quad$ Using the IMF regime data but restricting the sample to the observations for which LYS regime data are also available, to account for sampling differences between the two regime classifications.

- Adding regional dummies for the transition economies, South America, and Asia.

- $\quad$ Using the lagged values of the right-hand-side variables instead of their current values.

\footnotetext{
32 This is important for some transition economies, where credit to the public sector is considerable. For instance, Appendix Figure B1 shows that dollar credit to the private sector in Turkmenistan is low; however, dollar credit to the public sector in that country (not shown in the figure but available in the dataset) is large. Including these and related available data in the definition of credit dollarization and mismatches for this and other countries did not affect the benchmark results.

${ }^{33}$ For example, Appendix Figure B2 shows that Sao Tome and Principe has a very large mismatch. Since this country also has a floating regime, its inclusion might impact the result in the direction of associating floating with mismatching. It is therefore reassuring that the benchmark results hold even after excluding this and other unusual cases of large deposit-credit differences due to very low credit dollarization (e.g. Turkmenistan, Sao Tome and Principe) or deposit dollarization (e.g. Mexico).
} 
- Using year dummies as time effects instead of the time trend.

None of these sensitivity tests significantly changed the main results.

\subsection{Panel Data Estimation}

The cross-regime OLS analysis above is useful for answering the question: "How much more or less dollarization and mismatches do countries under flexible regimes have, compared to those under fixed regimes?" The fixed effect ("within") estimator exploits the time dimension of the panel data set around country averages and is therefore useful to answer a related question: "What is the effect of adopting a floating regime on dollarization and mismatches?" Both questions are very important in terms of policy-making. However, the latter is of paramount policy relevance, insofar as the majority view advocates that fixed-rate countries should adopt greater exchange rate flexibility. In answering this question, I still use one-year exclusion windows around regime changes, to avoid regime change contamination.

Results with the fixed effect estimator are shown in Table 6. For comparison, I also report random effect estimates. ${ }^{34}$ To save space, I henceforth report only the results scaling the dollarization series by total credit and deposits, as scaling by total assets and liabilities continues yielding qualitatively identical results. ${ }^{35}$ As before, the coefficient of the floating regime indicator in the credit dollarization regressions is negative but statistically insignificant. On the other hand, deposit dollarization is significantly greater after the adoption of floating regimes, as the fixed effect estimate shows. Remarkably, the coefficient of the floating regime indicator is almost identical in both the fixed and random effect regressions -- 4.5 per cent. Mismatches are significantly larger under floating regimes: as a share of total bank liabilities, they are 12 per cent larger in the fixed effects regression and 8 per cent larger in the random

\footnotetext{
${ }^{34}$ Results using the "between" estimator (not reported) suggest similar patterns. Results using the LYS data yield less precise fixed effect estimates, as the number of usable observations with LYS regimes is small.

${ }^{35}$ Similarly, from now on I only use inflation and maximum depreciation, as alternative estimations using various permutations of current and historical maximum rates of inflation and depreciation yield very similar results.
} 
effect regression. ${ }^{36}$ In sum, panel data results are very similar to those from pooled OLS regressions. ${ }^{37}$

\subsection{Endogeneity}

So far I have assumed that the exchange rate regime is exogenous with respect to dollarization. But the exchange rate regime is a policy decision, based in part on the financial characteristics of the economy. This raises at least the possibility of endogeneity.

There are reasons to think that endogeneity is not driving the results. Under high dollarization of bank liabilities (e.g. deposit dollarization) and large currency mismatches, the monetary authorities may be concerned about the potentially destabilizing impact of depreciation shocks. As a consequence, they may be inclined to implement and maintain a fixed exchange rate. ${ }^{38}$ In this context, endogeneity could create a bias in favor of floating regimes and lower dollarization and mismatches. But the results above suggest that the opposite is the case.

On the other hand, greater dollarization and mismatches may still force countries to float (for example, a currency crisis may be partly fueled by mismatches); however, the exclusion windows used throughout this analysis address this problem. At the same time, in a scenario of asset substitution like financial dollarization, the greater sensitivity of the exchange rate to portfolio reallocations by residents (which is the domestic equivalent to greater capital mobility) may create an additional incentive to adopt a more flexible exchange rate.

36 To further account for the persistence of dollarization, I also estimated fixed- and random-effect regressions allowing for autocorrelated disturbances. The results are less precise in both credit and deposit dollarization regressions. Nevertheless, the coefficient of the floating regime indicator is positive and significant in the mismatches regressions: the fixed effect coefficient is 11 per cent and the random effect coefficient is 8 per cent.

37 There is an important point to be made about these results. In order to exploit the time variation of the data using the within estimator, a sufficient number of switches from non-floating to floating regimes are needed. In my sample, there are 22 switches for the credit dollarization regressions, 48 switches for the deposit dollarization regressions, and 21 switches for the mismatch regressions. Ideally, an appropriate number of switches would be about 25 or 30 in number, as to make the within estimator viable. Nevertheless, despite the relatively small number of switches, the coefficient of the floating regime indicator in the fixed effect mismatch regression is large and significant at the 99 per cent confidence level.

${ }^{38}$ Poirson (2001) reports that countries with higher deposit dollarization are more likely to adopt a fixed exchange rate regime. 
To address these possibilities, I report instrumental variable estimations. The standard theory on optimal currency areas suggests that if real shocks are prevalent, a country may choose exchange rate flexibility. On the other hand, small economies have an incentive to peg their exchange rate. Therefore, I use terms-of-trade shocks and land area as instruments. As a third instrument, I use the value of the exchange rate regime (for intermediate and floating) in 1974 or, if 1974 regime data are not available, the earliest available year. Given that dollarization in most countries did not begin until after the early 1980s, the 1974 value of the regime should be regarded as plausibly exogenous or at least predetermined.

The results, reported in Table 7 , suggest that endogeneity does not drive the results. I report IV estimates along with their OLS counterparts for comparison. Deposit dollarization is still overwhelmingly and significantly higher under flexible exchange rate regimes. Note that the estimated coefficients of floating regimes in the deposit dollarization regressions are larger when they are estimated by instrumental variables: while the OLS estimate is 10 per cent, the IV estimate is 37 per cent. (Both of them are significant at the 99 per cent confidence level). This is evidence that the potential bias worked against the OLS results reported previously. On the other hand, the estimated impact of the floating regimes on credit dollarization is negative but insignificant regardless of estimation method. More importantly, the mismatch ratio is still greater under floating regimes after controlling for endogeneity; nevertheless, the point estimate of the floating regime indicator is statistically insignificant due to larger standard errors. ${ }^{39}$ However, while the Hausman test rejects the null hypothesis of exogeneity in the credit and deposit dollarization regressions, it fails to reject exogeneity in the mismatch regression (with a P-value of 0.3 ).

In order to assess the robustness of these findings and account for the dichotomous nature of the endogenous right-hand-side variables (the intermediate and floating regime dummies), I compute a second set of IV results. To that end, I proceed as follows. First, I estimate an ordered probit equation using the three exchange rate regimes as one polychotomous dependent variable and the instrumental variables mentioned above as regressors. Then, I use the fitted probabilities of the intermediate and floating regimes from this probit regression as

\footnotetext{
${ }^{39}$ I also estimated the regressions using political variables (such as the average number of revolutions and the average number of political crises during the sample period, using data from the Arthur S. Banks Cross National Time Series Data Archive) as additional instruments. The unreported results are qualitatively the same.
} 
instruments in a 2SLS estimation. The results are reported in Table 8 and are fairly similar to those reported in the preceding table. Credit dollarization is negatively but insignificantly linked with floating regimes, while deposit dollarization is significantly higher under flexibility, regardless of estimation method. Remarkably, the floating regime coefficient in the mismatch IV regression (14 per cent) is larger than its OLS counterpart (8 per cent) and it is statistically significant (at the 90 per cent confidence level). Again, the evidence suggests that any bias was working against the OLS results above. A Hausman test again fails to reject the null of exogeneity in the currency mismatch regression (with a P-value of 0.38).

In conclusion, IV estimates show that the results are not driven by potential endogeneity of the regime. ${ }^{40}$ In particular, it is fair to say that the OLS evidence reported earlier on a positive coefficient of floating regimes on the mismatch regressions is robust to endogeneity, as the IV estimations yield less efficient but still positive coefficients while formal tests fail to reject the null hypothesis of exogeneity.

\section{Discussion and Caveats}

Summing up, all the evidence presented in this paper yields the same message: floating regimes encourage deposit dollarization more strongly than they encourage matching via credit dollarization; as a result, they exacerbate currency mismatches in financial intermediation. The question is: Why does this robust stylized fact obtain?

As suggested in the Introduction, dollar loan default risk, and the trade-off between default risk and currency risk, may play an important role in shaping these results. However, empirical scrutiny on the role of default risk requires gathering data on the share of nonperforming dollar loans in a large number of countries and analyzing the links between exchange rate flexibility and dollar loan default rates. This is beyond the scope of this paper and is left for future research.

More generally, it is of paramount importance to study more closely the determinants of banks' supply of dollar loans in the context of risk management. Credit dollarization leads to diversification and redistribution of exchange risk that could in principle be stabilizing. The

\footnotetext{
${ }^{40}$ Analogous unreported estimations fixing the sample to a common number of observations for each IVOLS pair of regressions yield similar results.
} 
results in this paper suggest that banks in developing countries are not willing to transfer such a risk to firms - or, at least, they are not any more willing to do so under flexible exchange rates. If that is the case, we need to understand this issue better. ${ }^{41}$

That said, it is also important to keep a number of caveats in mind. A first and obvious caveat, already mentioned earlier in the paper, is that deposit-credit mismatches do not account for all the foreign currency exposure of banks. A bank facing a deposit-credit mismatch may hedge by purchasing dollar-denominated securities. It may also conduct off-balance sheet transactions and buy insurance in forward markets. Regrettably, the necessary data to analyze these issues more closely are non-existent for a large number of countries. In that sense, the results in this paper do not necessarily show that banks unambiguously hedge less under floating regimes; instead, these results imply that banks need to hedge more (elsewhere in their balance sheets or in insurance markets) if they wish to cover the increasing deposit-credit mismatches that result from exchange rate flexibility.

A second caveat, also mentioned previously, relates to domestic- and foreign-currency lending and deposit interest rates, as well as the corresponding spreads. These interest rates may be adjusted in order to help compensate existing mismatches and reduce overall risk. But again, lack of data is a major limitation to further study this matter.

A third caveat is the presence of foreign banks in several dollarized economies. A foreign bank may choose to leave some liabilities unhedged in country A but may hold excess dollar assets in country B. If so, it may be perfectly hedged, even though data in country A give the impression that it is not. Pursuing this issue further would require reliable micro-level data on the currency denomination and location of assets and liabilities of foreign banks, which are not readily available.

Finally, a fourth caveat is whether there can be an "optimal" degree of mismatch in financial intermediation. It is not clear whether a perfectly matched banking system exhibits lower overall risk than a slightly mismatched one, given the trade-off between currency risk and default risk. And the slightly mismatched banking system may compensate its greater

\footnotetext{
${ }^{41}$ This analysis has largely ignored dollar credit demand by firms and dollar deposit demand by banks. In particular, it has assumed that changes in dollar volumes are mainly supply-driven. While the focus of this paper on equilibrium volumes of loans and deposits minimizes this limitation, further research is clearly desirable to identify the effects of exchange rate flexibility on both supply and demand of dollar credits and deposits.
} 
deposit-credit mismatch by holding more dollar securities. Of course, whether it is socially optimal that banks hold a greater proportion of their dollar assets in the form of securities in international markets, rather than in the form of credit to finance productive domestic investment, represents an additional welfare issue to consider. Both theoretical and empirical research on that direction is needed.

\section{Concluding Remarks}

The currency and financial crises of the 1990s reignited the debate on the impact of exchange rate regimes. One aspect of that debate concerns the links between the exchange rate regime and currency mismatches. The majority view on the issue has it that greater flexibility encourages banks and firms to limit their foreign currency exposure. This view is appealing and generally accepted by many. Nevertheless, it has never been tested systematically.

This paper is the first attempt to test it. I study whether flexible exchange rate regimes are associated with lower currency mismatches in financial intermediation. To that end, I assemble a comprehensive database on the dollarization of bank deposits and credit in a large number of developing and transition economies, along with accompanying bank regulatory arrangements.

The results do not support the presumption that flexibility is associated with a reduction of currency mismatches in the banking systems of financially dollarized countries. Most (if not all) of the evidence goes against such a presumption. Floating exchange rate regimes encourage deposit dollarization more strongly than they encourage credit dollarization. Therefore, currency mismatches in financial intermediation are more severe under exchange rate flexibility. These results are robust to the inclusion of a variety of controls, different definitions of dollarization and mismatches, the presence of outliers, different specifications, different estimation methods, and the potential presence of endogeneity.

If these results are right, and insofar as currency mismatches in financial intermediation are an important component of banks' overall foreign currency exposures, they constitute the first systematic evidence that flexible exchange rate regimes may not alleviate - and may actually exacerbate -- such exposures in developing countries. This is an important implication, deserving serious attention. If this is indeed the case, policymakers in dollarized economies, as well as academics and multilateral organizations, might wish to reassess whether greater 
exchange rate flexibility, by itself, will reduce banks' open foreign currency positions. Of course, further research is needed to conclude whether these results apply to overall currency mismatches in banks' - and firms' - balance sheets, as well as to hedged and unhedged exposures in insurance markets. Until that research is done, however, the burden of proof is on the majority view's side. Perhaps it is time to look at the minority view more seriously. 


\section{References}

Baliño, Tomás, Adam Bennett, and Eduardo Borensztein (1999), "Monetary Policy in Dollarized Economies," International Monetary Fund Occasional Paper 171 (March).

Barth, James, Gerard Caprio, and Ross Levine (2001), “The Regulation and Supervision of Banks Around the World: A New Database," World Bank Policy Research Paper 2588 (February).

Berg, Andrew and Eduardo Borensztein (1999), "The Choice of Exchange Rate Regime and Monetary Target in Highly Dollarized Economies," International Monetary Fund Working Paper 00/29 (February).

Burnside, Craig, Martin Eichenbaum, and Sergio Rebelo (2000), "Hedging and Financial Fragility in Fixed Exchange Rate Regimes," unpublished manuscript, World Bank and Northwestern University (October).

Caballero, Ricardo and Arvind Krishnamurthy (2000), "Dollarization of Liabilities: Underinsurance and Domestic Financial Underdevelopment," National Bureau of Economic Research Working Paper 7792 (July).

Calvo, Guillermo and Carmen Reinhart (2000a), "Fear of Floating," National Bureau of Economic Research Working Paper 7993 (November).

Calvo, Guillermo and Carmen Reinhart (2000b), "Fixing for Your Life," National Bureau of Economic Research Working Paper 8006 (November).

Calvo, Guillermo and Carlos Végh (1992), "Currency Substitution in Developing Countries: An Introduction," Revista de Análisis Económico 7, pp. 3-27.

Calvo, Guillermo and Carlos Végh (1996), "From Currency Substitution to Dollarization and Beyond: Analytical and Policy Issues," in Guillermo Calvo, Money, Exchange Rates and Output, Cambridge: MIT Press, pp. 153-175.

Catão, Luis and Marco Terrones (2000), "Determinants of Dollarization: The Banking Side," International Monetary Fund Working Paper 00/146, (August).

Demirgüç-Kunt, Asli and Enrica Detragiache (2000), “Does Deposit Insurance Increase Banking System Stability?" International Monetary Fund Working Paper 00/3 (January).

Demirgüç-Kunt, Asli, Enrica Detragiache, and Poonam Gupta (2000), "Inside the Crisis: An Empirical Analysis of Banking Systems in Distress," International Monetary Fund Working Paper 00/156 (October).

Eichengreen, Barry (2000), "Solving the Currency Conundrum," unpublished manuscript, University of California at Berkeley (March). 
Eichengreen, Barry and Ricardo Hausmann (1999), “Exchange Rates and Financial Fragility," National Bureau of Economic Research Working Paper 7418 (November).

Frankel, Jeffrey (1999), "No Single Currency Regime is Right for All Countries or at All Times," National Bureau of Economic Research Working Paper 7338 (September).

Ghosh, Atish, Anne-Marie Gulde, Jonathan Ostry, and Holger Wolf (1997), “Does the Nominal Exchange Rate Regime Matter?" National Bureau of Economic Research Working Paper 5874 (January).

Giovannini, Alberto and Bart Turtelboom (1994), "Currency Substitution," in Frederick van der Ploeg (ed.), Handbook of International Macroeconomics, Cambridge: Blackwell Publishers, pp. 390-436.

Goldstein, Morris (2002), Managed Floating Plus, Policy Analyses in International Economics 66, Washington, D.C.: Institute for International Economics (March).

International Monetary Fund (2000), International Financial Statistics, Washington, D.C.: International Monetary Fund.

International Monetary Fund (various years), Annual Report on Exchange Arrangements and Exchange Restrictions, Washington, D.C.: International Monetary Fund.

Ize, Alain and Eduardo Levy-Yeyati (1998), "Dollarization of Financial Intermediation: Causes and Policy Implications," International Monetary Fund Working Paper 98/28 (March).

Levy-Yeyati, Eduardo and Federico Sturzenegger (2000), “Classifying Exchange Rate Regimes: Deeds vs. Words," unpublished manuscript, Universidad Torcuato di Tella (November).

McKinnon, Ronald (2001), “The East Asian Dollar Standard, Life After Death?" in Joseph Stiglitz and Shahid Yusuf (eds.), Rethinking the East Asian Miracle, World Bank and Oxford University Press.

McNelis, Paul and Liliana Rojas-Suárez (1996), “Exchange-Rate Depreciation, Dollarization and Uncertainty: A Comparison of Bolivia and Peru," Inter-American Development Bank Working Paper 325 (March).

Mishkin, Frederic (1996), “Understanding Financial Crises: A Developing Country Perspective," in Michael Bruno and Boris Pleskovic (eds.), Annual World Bank Conference on Development Economics 1996, Washington, D.C., pp. 29-62.

Obstfeld, Maurice (1998), “The Global Capital Market: Benefactor or Menace?" Journal of Economic Perspectives 12, pp. 9-30.

Poirson, Hélène (2001), “How Do Countries Choose Their Exchange Rate Regime?" International Monetary Fund Working Paper 01/46 (April). 
Savastano, Miguel (1992), "The Pattern of Currency Substitution in Latin America: An Overview," Revista de Análisis Económico 7, pp. 29-72.

Savastano, Miguel (1996), “Dollarization in Latin America: Recent Evidence and Policy Issues," in Paul Mizen and Eric Pentecost (eds.), The Macroeconomics of International Currencies, Cheltenham: Edward Elgar Publishing, pp. 225-255.

World Bank (2000), World Development Indicators, Washington, D.C.: World Bank. 


\section{A Data Appendix}

\section{A.1 Data Definitions and Sources}

Abbreviations: AREAER: IMF Annual Report on Exchange Arrangements and Exchange Restrictions country pages (various issues). CB: Central Bank bulletins (various countries/issues). IFS: IMF International Financial Statistics. MBS: IMF Money and Banking Statistics data. WDI: World Bank World Development Indicators.

\section{Dollarization Data}

\section{Raw Data}

- Total credit to the resident private sector issued by resident banks. Source: line 22d of IFS.

- Foreign-currency-denominated ("dollar") credit to the resident private sector issued by resident banks. Sources: CB and MBS.

- $\quad$ Total assets of resident banks. Sources: CB and MBS.

- Total deposits of residents held in resident banks. Source: lines 24 plus line 25 of IFS.

- $\quad$ Foreign-currency-denominated ("dollar") deposits of residents held in resident banks. Sources: CB, MBS, and lines 25.a and 25b of IFS.

- Total liabilities of resident banks. Sources: CB and MBS.

\section{Definition of Dependent Variables}

- Credit dollarization (percent). First definition: ratio of dollar credit to total credit. Second definition: ratio of dollar credit to total assets.

- Deposit dollarization (percent). First definition: ratio of dollar deposits to total deposits. Second definition: ratio of dollar deposits to total liabilities.

- $\quad$ Currency mismatches (percent): Ratio of gap between dollar deposits and dollar credit to total liabilities [i.e. (dollar deposits - dollar credit) * 100 / (total liabilities)].

\section{Exchange Rate Regime Data}

Default classification: IMF regimes. Source: AREAER. (Revised and corrected using information provided by Virgilio Sandoval and Holger Wolf, via personal correspondence.) 
- $\quad$ Fixed regimes: binary for fixed exchange rate regimes against a particular currency, a basket of currencies, or SDR.

- Intermediate regimes: binary for limited flexibility or managed floats with a preannounced path for the exchange rate.

- $\quad$ Floating regimes: binary for managed floats with no pre-announced path for the exchange rate or independent floats.

Alternative classification (for sensitivity analysis): LYS regimes. Source: Levy-Yeyati and Sturzenegger (2000). See their paper for definitions of fixed, intermediate, and floating regimes. Fixed regimes in this paper include their "high-credibility pegs" group.

\section{Regulatory Controls}

- $\quad$ Foreign currency loans allowed: binary for whether or not dollar loans are freely or almost freely allowed. Source: AREAER, other IMF publications.

- $\quad$ Foreign currency deposits allowed: binary for whether or not dollar deposits are freely or almost freely allowed. Source: AREAER, other IMF publications.

\section{Other Controls}

- Interest rate differentials (percentage points): difference of line $60 \mathrm{~b}$ of IFS with that of the United States. If line $60 \mathrm{~b}$ is unavailable, line $60 \mathrm{c}$ is used. If line $60 \mathrm{c}$ is unavailable, line 60 is used. Source: IFS

- $\quad$ Trade (percent): ratio of exports plus imports to GDP. Source: WDI.

- Inflation (percent): percentage change of CPI, as reported by source. If series is unavailable, percentage change of GDP deflator, as reported by source. Source: WDI.

- $\quad$ Depreciation (percent): first difference of the log of the nominal exchange rate ${ }^{*} 100$. Source: WDI.

- Maximum historical inflation: running maximum value of inflation rate (as defined in the text).

- Maximum historical depreciation: running maximum value of depreciation rate (as defined in the text).

- Forward market indicator: binary for whether a forward market was reported to exist, as opposed to being reported to be underdeveloped, heavily regulated, or nonexistent. Source: AREAER. 
- Deposit insurance: binary for whether there is an explicit deposit insurance scheme that covers foreign currency accounts. Source: Demirgüç-Kunt and Detragiache (2000).

\section{Instruments}

- $\quad$ Terms-of-trade shocks (percent): first difference of the log of terms-of-trade index in goods and services * 100 . Source: WDI.

- $\quad$ Land area in squared kilometers. Source: WDI.

- Initial exchange rate regime: IMF regime in 1974 or earliest year available. Source: AREAER. 


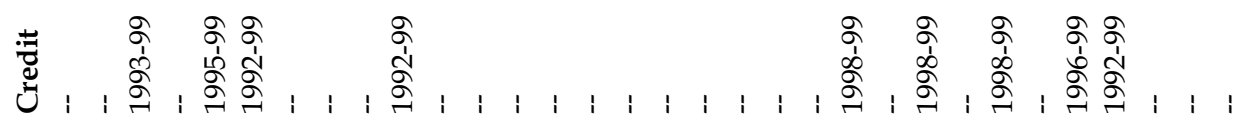

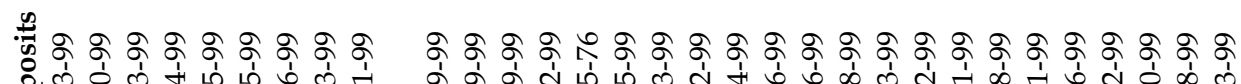

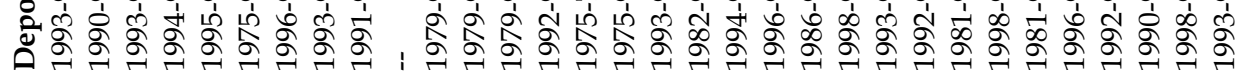

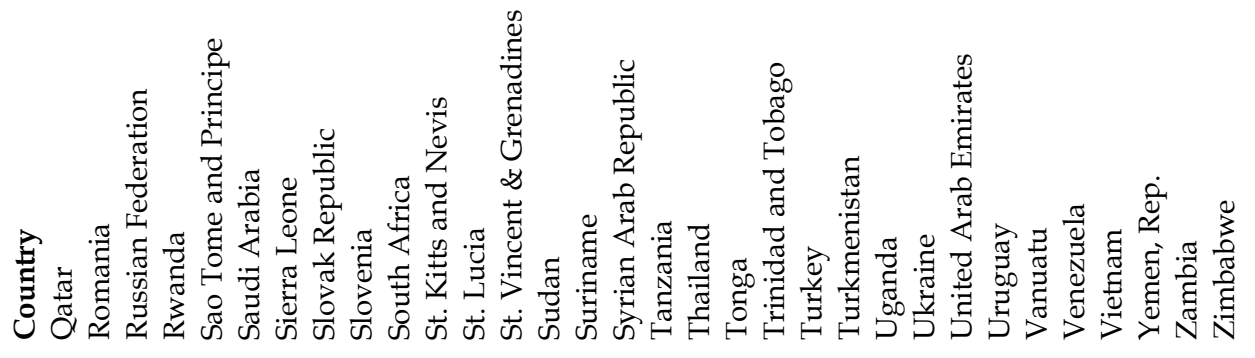

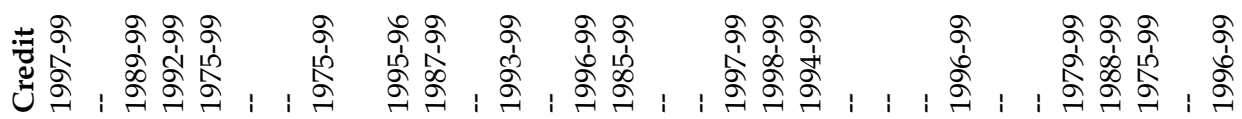

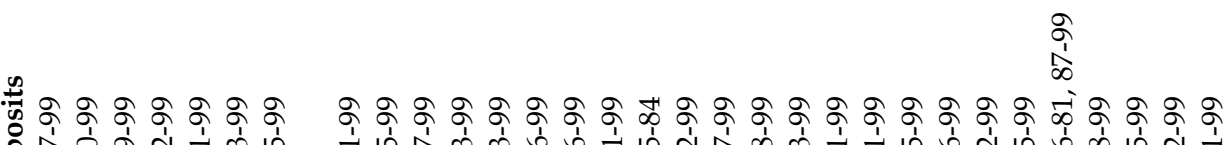

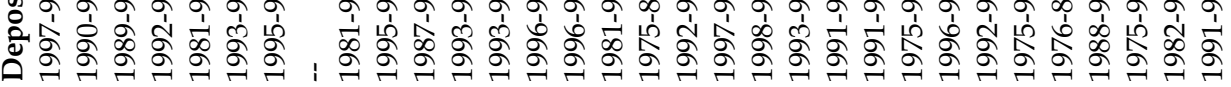

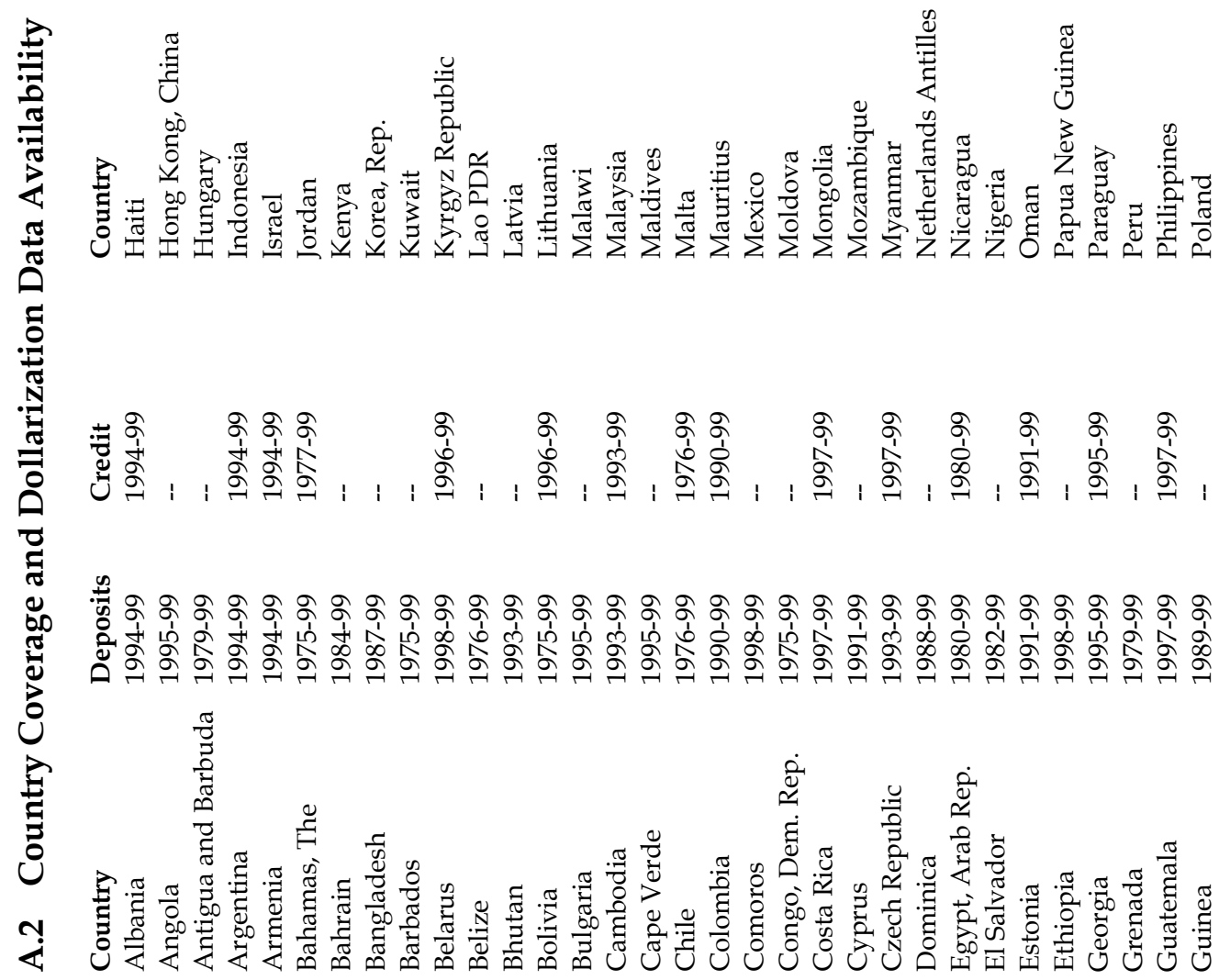




\section{B Graphical Appendix for Selected Countries}

Figure B1: Financial Dollarization, Non-Floaters
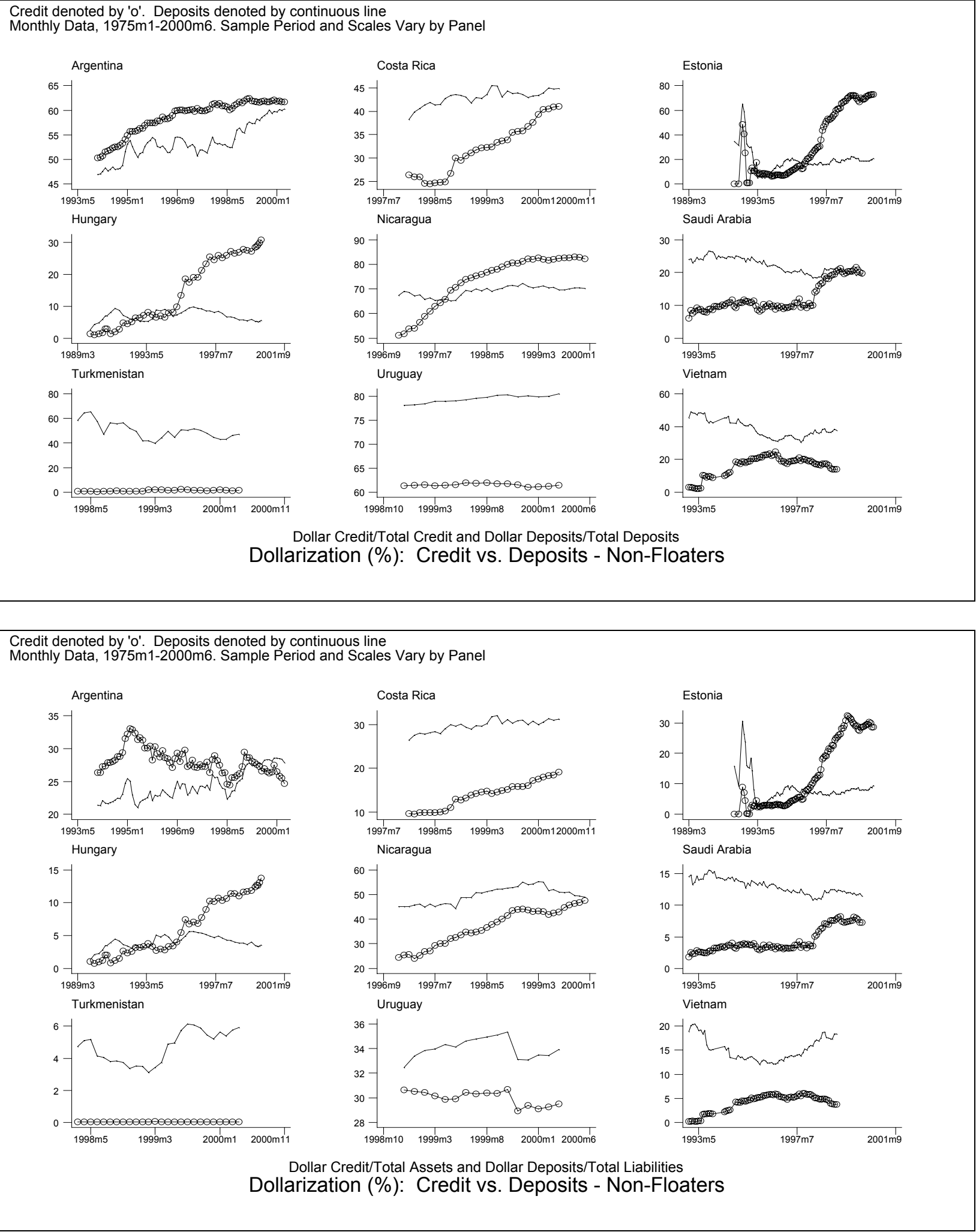
Figure B2: Financial Dollarization, Floaters

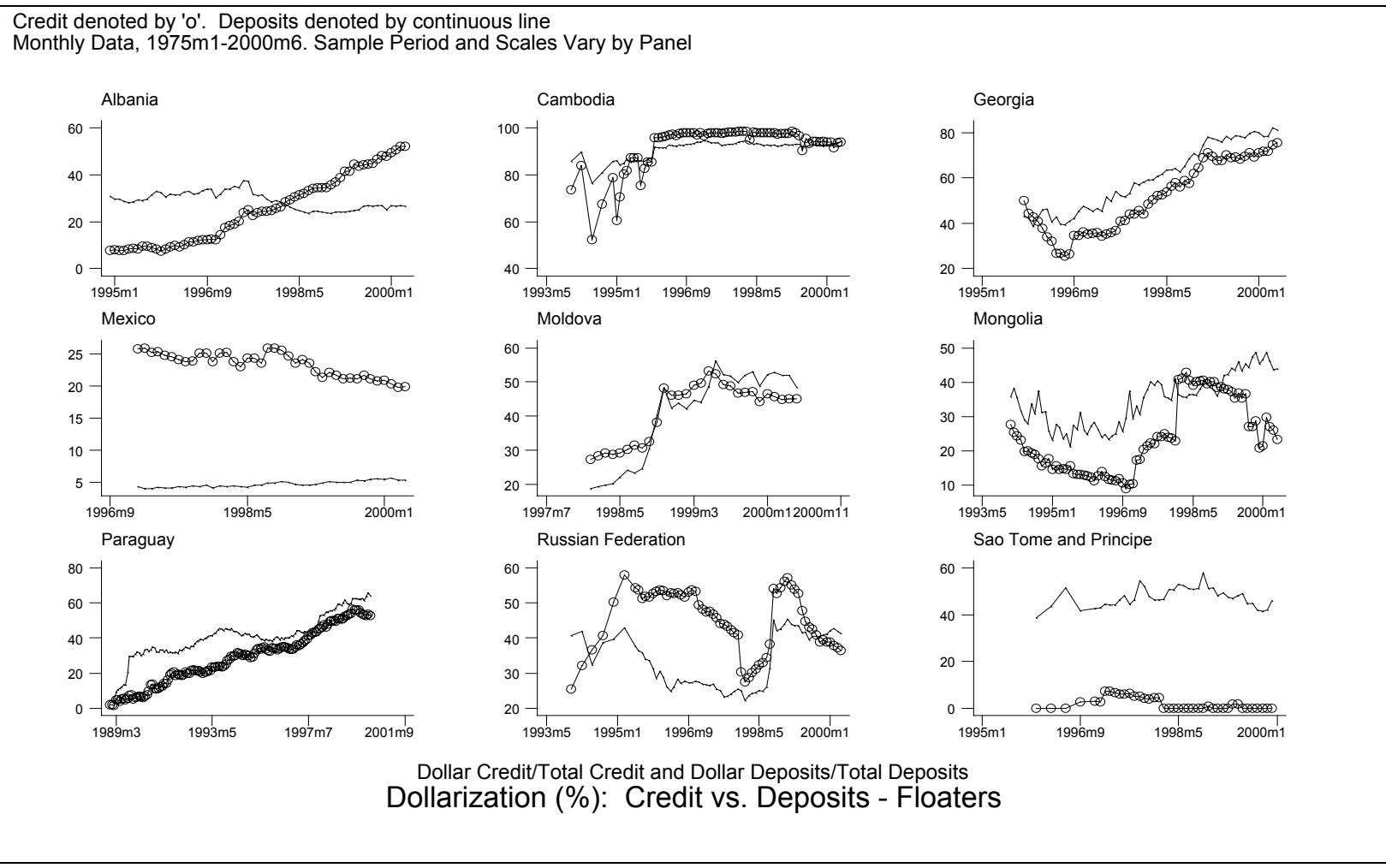

Credit denoted by 'o'. Deposits denoted by continuous line

Monthly Data, 1975m1-2000m6. Sample Period and Scales Vary by Panel
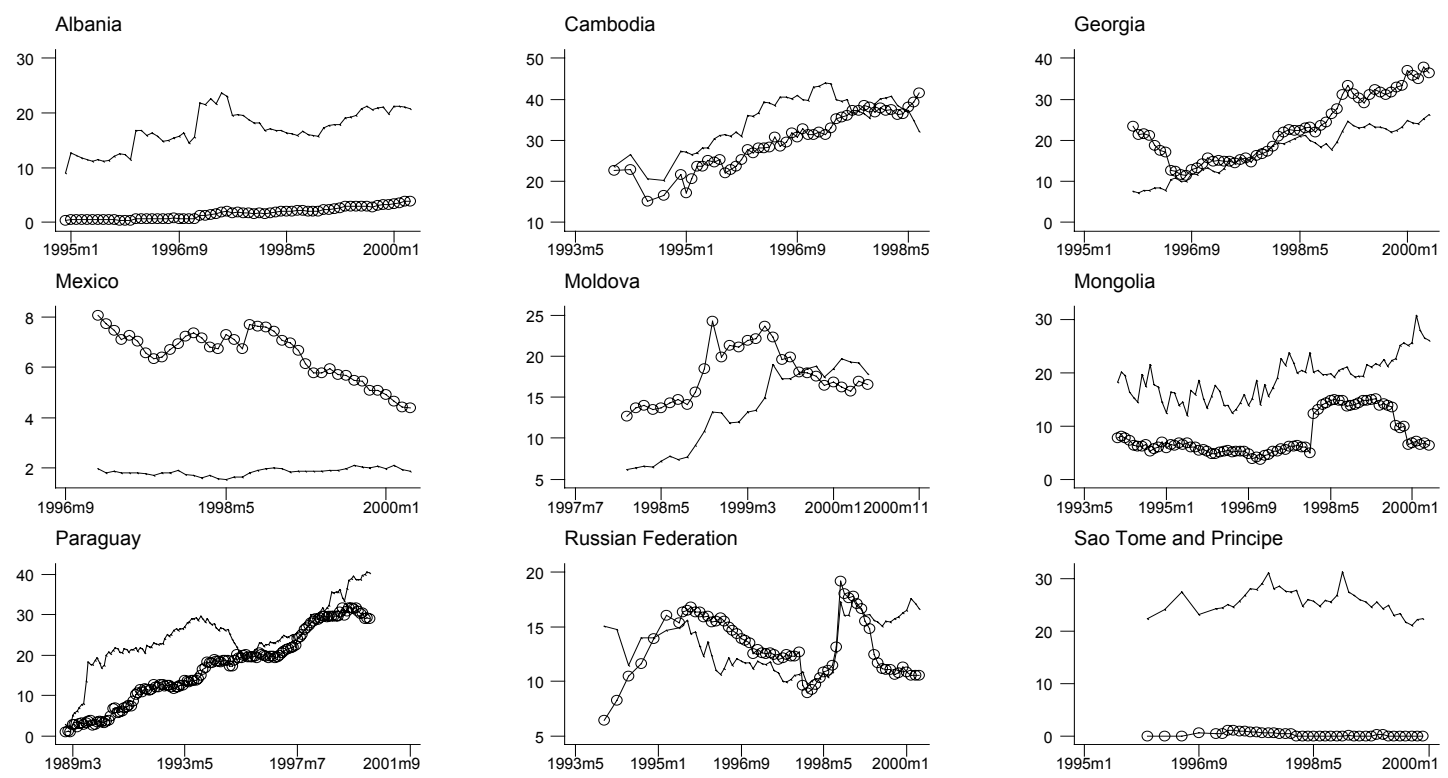

Dollar Credit/Total Assets and Dollar Deposits/Total Liabilities Dollarization (\%): Credit vs. Deposits - Floaters 


\section{Figure B3: Financial Dollarization, Countries Under Several Regimes}

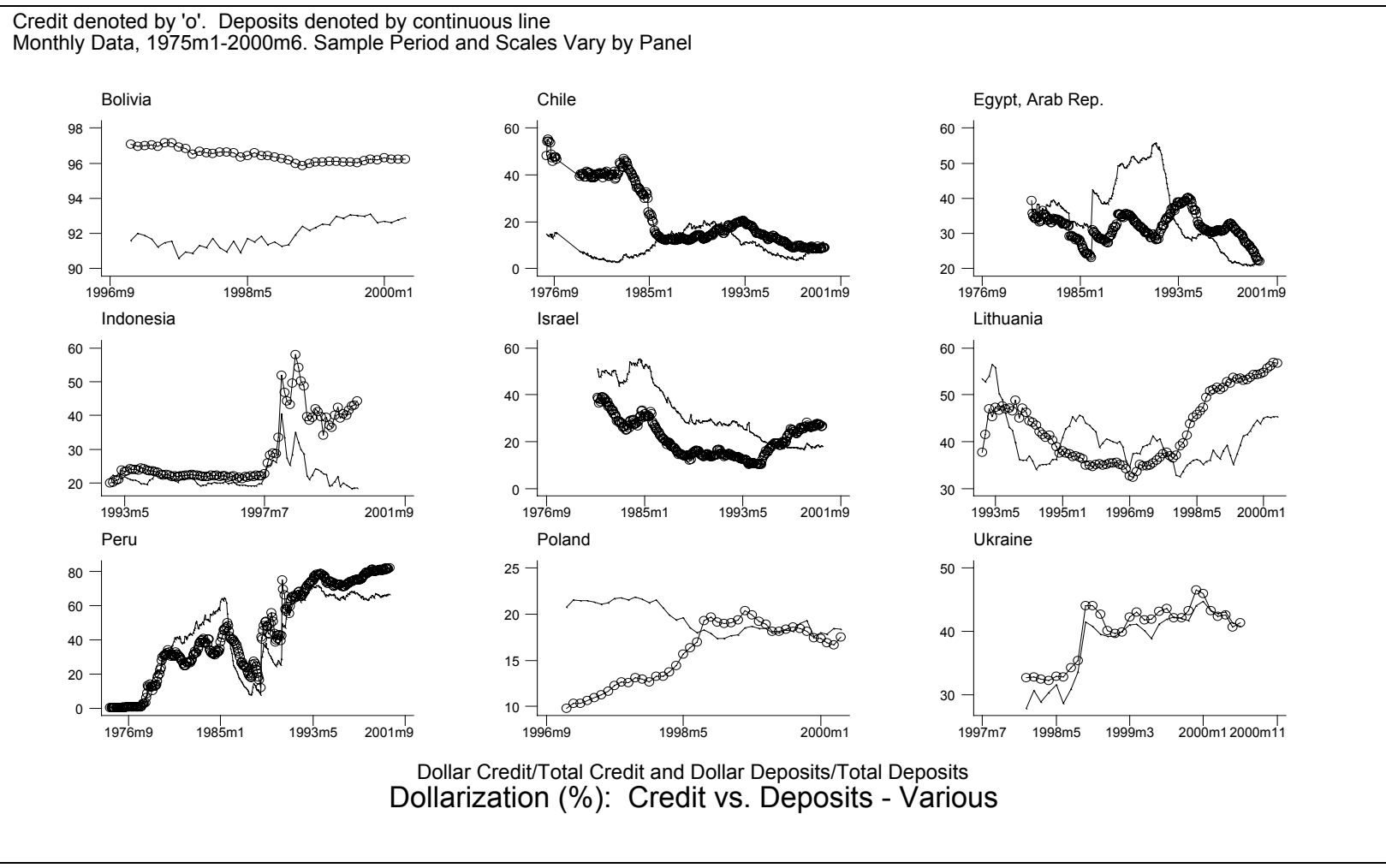

Credit denoted by 'o'. Deposits denoted by continuous line

Monthly Data, 1975m1-2000m6. Sample Period and Scales Vary by Panel
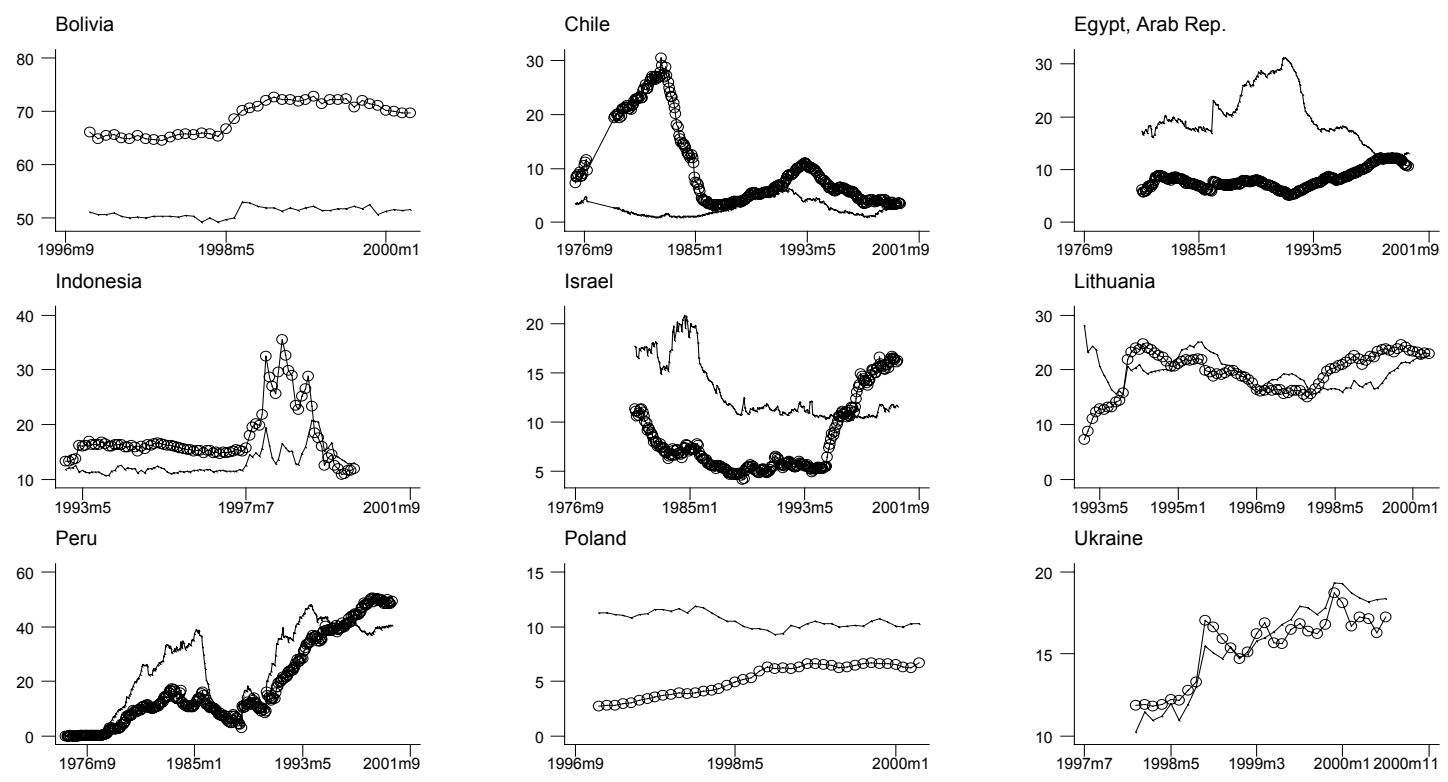

Dollar Credit/Total Assets and Dollar Deposits/Total Liabilities Dollarization (\%): Credit vs. Deposits - Various Regimes 
Figure and Tables

Figure 1: Effect of Floating Regime Adoption

Floating Regime Onset; Non-Floating Mean Marked.

Data Vary by Panel.

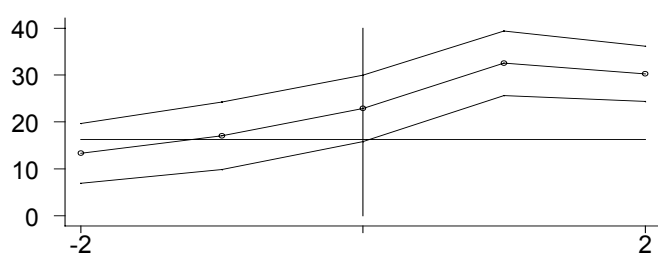

Dollar Deposits/Total Deposits

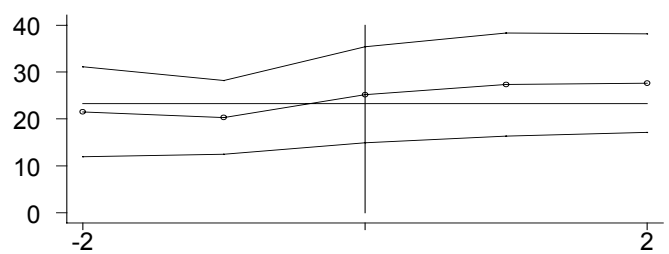

Dollar Credit/Total Credit

Mean plus two standard deviation band; all figures are percentages. Movements 2 Years Before \& After Floating Regime Adoption

\section{Floating Regime Onset; Non-Floating Mean Marked Data Vary by Panel.}

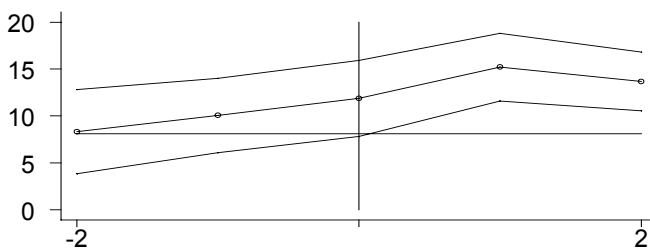

Dollar Deposits/Total Liabilities

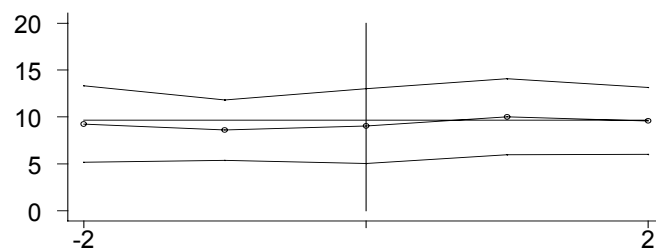

Dollar Credit/Total Assets

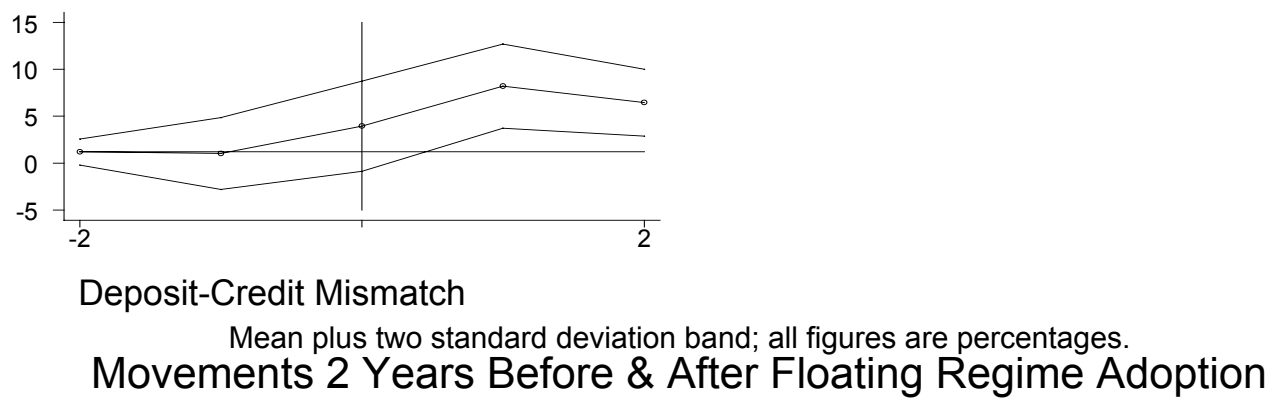


Note: In all tables below, a two-sided, one-year exclusion window around floating regime adoptions is used.

Table 1

Descriptive Statistics

\begin{tabular}{clllll}
\hline \hline & $\begin{array}{l}(1) \\
\text { Dollar Credit/ } \\
\text { Total Credit }\end{array}$ & $\begin{array}{l}(2) \\
\text { Dollar Deposit/ } \\
\text { Total Deposit }\end{array}$ & $\begin{array}{l}(3) \\
\text { Dollar Credit/ } \\
\text { Total Assets }\end{array}$ & $\begin{array}{l}(4) \\
\text { Dollar Deposit/ } \\
\text { Total Liabilities }\end{array}$ & $\begin{array}{l}(5) \\
\text { Deposit-Credit } \\
\text { Mismatch }\end{array}$ \\
\hline \hline All & & & & & \\
Countries & 40 & 92 & 39 & 88 & 37 \\
$\quad$ Observations & 358 & 1018 & 352 & 929 & 314 \\
$\quad$ Mean & 27.23 & 21.64 & 10.95 & 10.38 & 2.83 \\
$\quad$ Std. Deviation & 23.32 & 22.10 & 11.88 & 11.43 & 9.42 \\
\hline Fixed Regimes & & & & & \\
$\quad$ Observations & 108 & 515 & 108 & 498 & 98 \\
Mean & 21.86 & 12.83 & 7.77 & 6.49 & 0.27 \\
Std. Deviation & 18.45 & 17.99 & 9.05 & 10.00 & 8.44 \\
\hline Intermediate & & & & & \\
Regimes & & & & & \\
Observations & 123 & 185 & 123 & 160 & 106 \\
$\quad$ Mean & 24.47 & 25.77 & 11.32 & 13.81 & 2.17 \\
$\quad$ Std. Deviation & 20.73 & 19.86 & 12.26 & 12.10 & 9.66 \\
\hline Floating Regimes & & & & & \\
Observations & 97 & 226 & 91 & 193 & 82 \\
Mean & 36.56 & 37.01 & 14.15 & 17.01 & 6.17 \\
$\quad$ Std. Deviation & 28.21 & 22.57 & 13.13 & 10.19 & 9.35 \\
\hline \hline
\end{tabular}

Table 2

Comparison of Means Across Exchange Rate Regimes

\begin{tabular}{llllll}
\hline \hline & $(1)$ & $(2)$ & $(3)$ & $(4)$ & $(5)$ \\
& $\begin{array}{l}\text { Dollar Credit/ } \\
\text { Total Credit }\end{array}$ & $\begin{array}{l}\text { Dollar Deposit/ } \\
\text { Total Deposit }\end{array}$ & $\begin{array}{l}\text { Dollar Credit/ } \\
\text { Total Assets }\end{array}$ & $\begin{array}{l}\text { Dollar Deposit/ } \\
\text { Total Liabilities }\end{array}$ & $\begin{array}{l}\text { Deposit-Credit } \\
\text { Mismatch }\end{array}$ \\
\hline \hline Intermediate & 1.019 & $12.104^{* * *}$ & $2.766^{* *}$ & $6.476^{* * *}$ & 2.227 \\
Regime & $(2.657)$ & $(1.663)$ & $(1.372)$ & $(1.070)$ & $(1.357)$ \\
\hline Floating & $14.768^{* * *}$ & $24.714^{* * *}$ & $6.503^{* * *}$ & $10.706^{* * *}$ & $6.260^{* * *}$ \\
Regime & $(3.449)$ & $(1.707)$ & $(1.671)$ & $(0.870)$ & $(1.407)$ \\
\hline Constant & $21.791^{* * *}$ & $12.297^{* * *}$ & $7.651^{* * *}$ & $6.302^{* * *}$ & -0.086 \\
& $(1.921)$ & $(0.814)$ & $(0.949)$ & $(0.468)$ & $(0.955)$ \\
\hline \hline Observations & 300 & 868 & 294 & 797 & 259 \\
\hline Adjusted R $\mathrm{R}^{2}$ & 0.08 & 0.23 & 0.05 & 0.16 & 0.07 \\
\hline \hline
\end{tabular}

Pooled OLS regressions. Robust standard errors in parentheses.

${ }^{*}$ significant at $10 \% ;{ }^{* *}$ significant at $5 \%$; ${ }^{* *}$ significant at $1 \%$. 


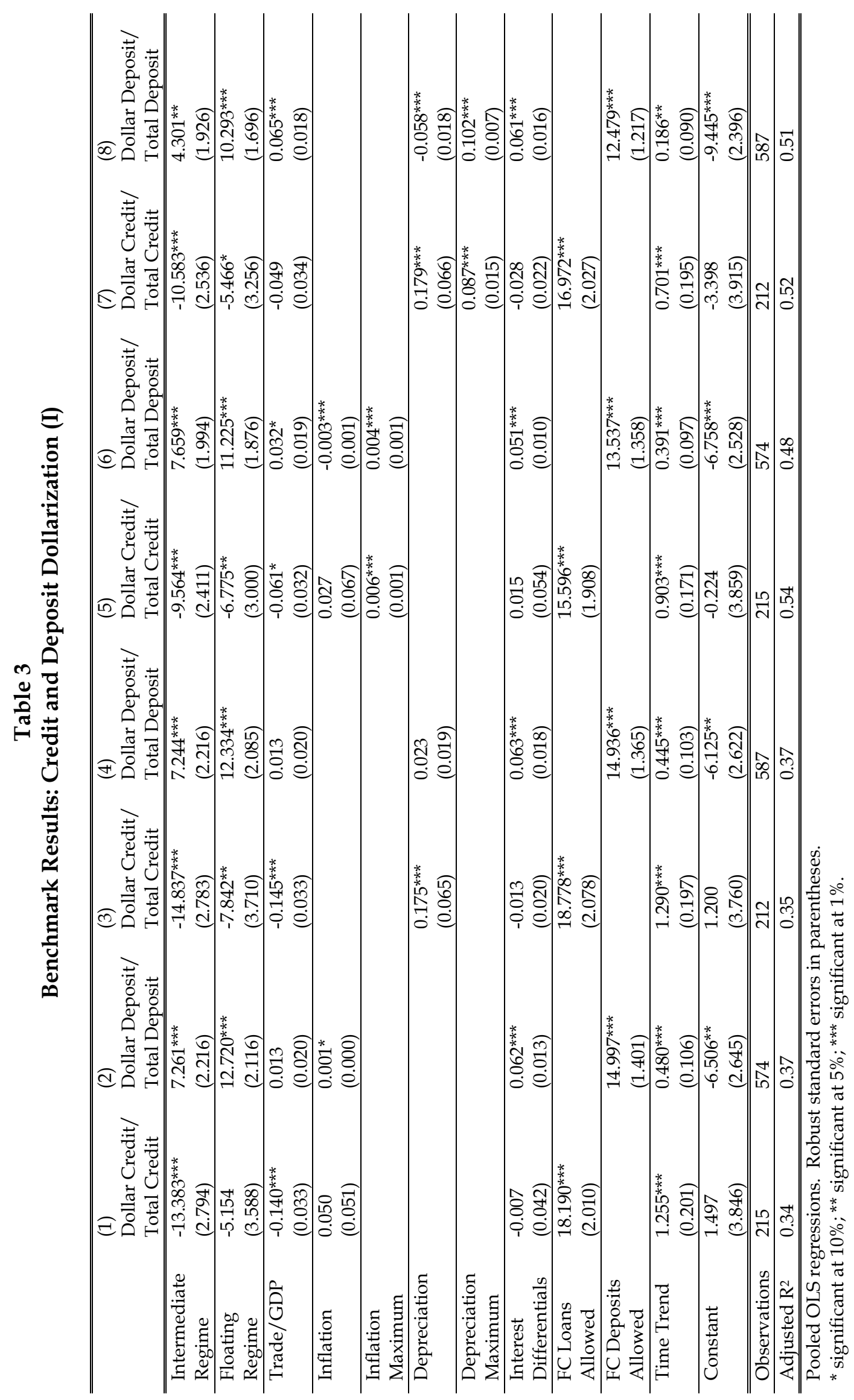




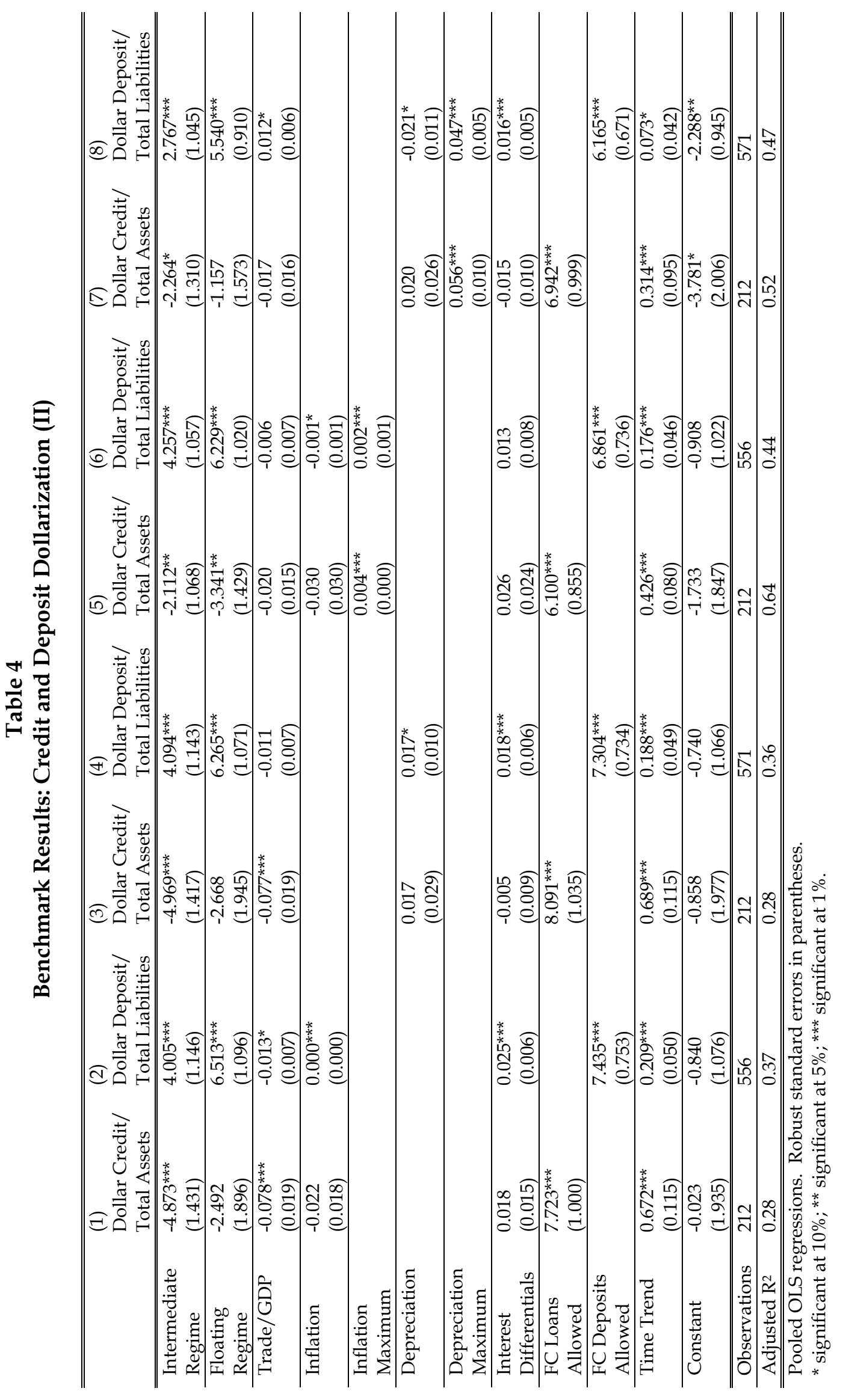

n 
Table 5

Benchmark Results: Currency Mismatches in Financial Intermediation

\begin{tabular}{|c|c|c|c|c|}
\hline & $\begin{array}{l}(1) \\
\text { Deposit-Credit } \\
\text { Mismatch }\end{array}$ & $\begin{array}{l}(2) \\
\text { Deposit-Credit } \\
\text { Mismatch }\end{array}$ & $\begin{array}{l}\text { (3) } \\
\text { Deposit-Credit } \\
\text { Mismatch }\end{array}$ & $\begin{array}{l}(4) \\
\text { Deposit-Credit } \\
\text { Mismatch }\end{array}$ \\
\hline $\begin{array}{l}\text { Intermediate } \\
\text { Regime }\end{array}$ & $\begin{array}{l}3.564^{*} \\
(1.830)\end{array}$ & $\begin{array}{l}3.274^{*} \\
(1.815)\end{array}$ & $\begin{array}{l}0.560 \\
(1.601)\end{array}$ & $\begin{array}{l}3.222^{*} \\
(1.897)\end{array}$ \\
\hline $\begin{array}{l}\text { Floating } \\
\text { Regime }\end{array}$ & $\begin{array}{l}8.148^{* * *} \\
(1.700)\end{array}$ & $\begin{array}{l}7.161^{* * *} \\
(1.707)\end{array}$ & $\begin{array}{l}6.510^{* * *} \\
(1.542)\end{array}$ & $\begin{array}{l}7.145^{* * *} \\
(1.729)\end{array}$ \\
\hline Trade/GDP & $\begin{array}{l}0.009 \\
(0.015) \\
\end{array}$ & $\begin{array}{l}0.007 \\
(0.016)\end{array}$ & $\begin{array}{l}-0.021 \\
(0.016)\end{array}$ & $\begin{array}{l}0.005 \\
(0.017)\end{array}$ \\
\hline Inflation & $\begin{array}{l}0.029 \\
(0.027)\end{array}$ & & $\begin{array}{l}0.032 \\
(0.030)\end{array}$ & \\
\hline Depreciation & & $\begin{array}{l}0.081^{*} \\
(0.045)\end{array}$ & & $\begin{array}{l}0.080^{*} \\
(0.045)\end{array}$ \\
\hline $\begin{array}{l}\text { Inflation } \\
\text { Maximum } \\
\end{array}$ & & & $\begin{array}{l}-0.001^{* * *} \\
(0.000)\end{array}$ & \\
\hline $\begin{array}{l}\text { Depreciation } \\
\text { Maximum }\end{array}$ & & & & $\begin{array}{l}-0.001 \\
(0.007)\end{array}$ \\
\hline $\begin{array}{l}\text { Interest } \\
\text { Differentials }\end{array}$ & $\begin{array}{l}-0.014 \\
(0.021)\end{array}$ & $\begin{array}{l}-0.011 \\
(0.012)\end{array}$ & $\begin{array}{l}-0.016 \\
(0.024)\end{array}$ & $\begin{array}{l}-0.011 \\
(0.012)\end{array}$ \\
\hline $\begin{array}{l}\text { FC Loans } \\
\text { Allowed }\end{array}$ & $\begin{array}{l}-3.194^{*} \\
(1.723)\end{array}$ & $\begin{array}{l}-3.479^{*} \\
(1.826) \\
\end{array}$ & $\begin{array}{l}-2.829^{*} \\
(1.672)\end{array}$ & $\begin{array}{l}-3.450^{*} \\
(1.857)\end{array}$ \\
\hline $\begin{array}{l}\text { FC Deposits } \\
\text { Allowed }\end{array}$ & $\begin{array}{l}3.476 \\
(2.299)\end{array}$ & $\begin{array}{l}4.105^{*} \\
(2.351)\end{array}$ & $\begin{array}{l}3.635 \\
(2.273)\end{array}$ & $\begin{array}{l}4.111^{*} \\
(2.369)\end{array}$ \\
\hline Time Trend & $\begin{array}{l}-0.404^{* * *} \\
(0.114)\end{array}$ & $\begin{array}{l}-0.417^{* * *} \\
(0.121)\end{array}$ & & $\begin{array}{l}-0.408^{* * *} \\
(0.125)\end{array}$ \\
\hline Constant & $\begin{array}{l}5.711^{*} \\
(3.163) \\
\end{array}$ & $\begin{array}{l}5.722^{*} \\
(3.185) \\
\end{array}$ & $\begin{array}{l}2.317 \\
(2.607) \\
\end{array}$ & $\begin{array}{l}5.793^{*} \\
(3.232)\end{array}$ \\
\hline Observations & 177 & 177 & 177 & 177 \\
\hline Adjusted R2 & 0.12 & 0.13 & 0.16 & 0.13 \\
\hline
\end{tabular}

Pooled OLS regressions. Robust standard errors in parentheses.

${ }^{*}$ significant at $10 \%$; ** significant at $5 \%$; ${ }^{* *}$ significant at $1 \%$. 


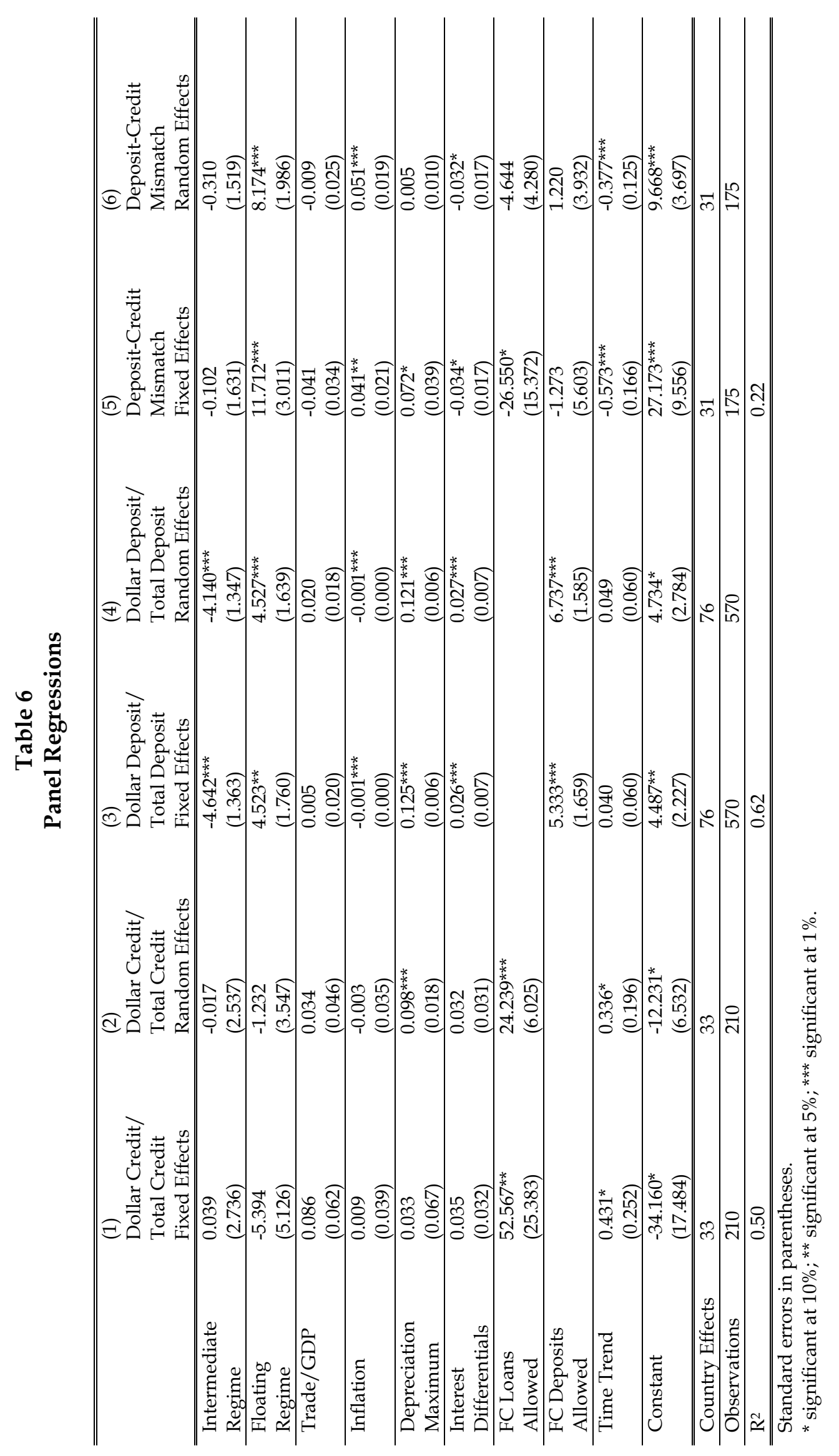




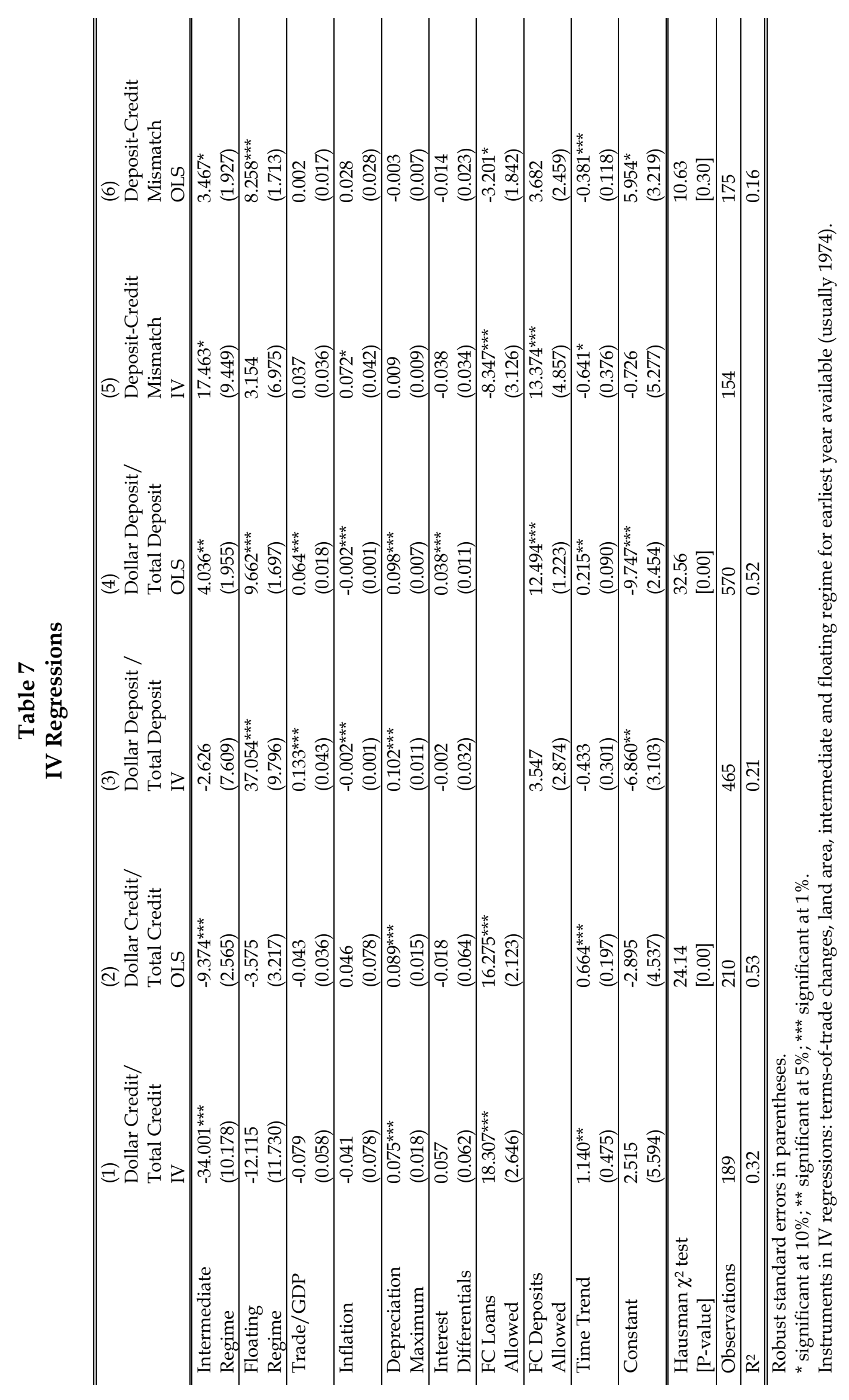




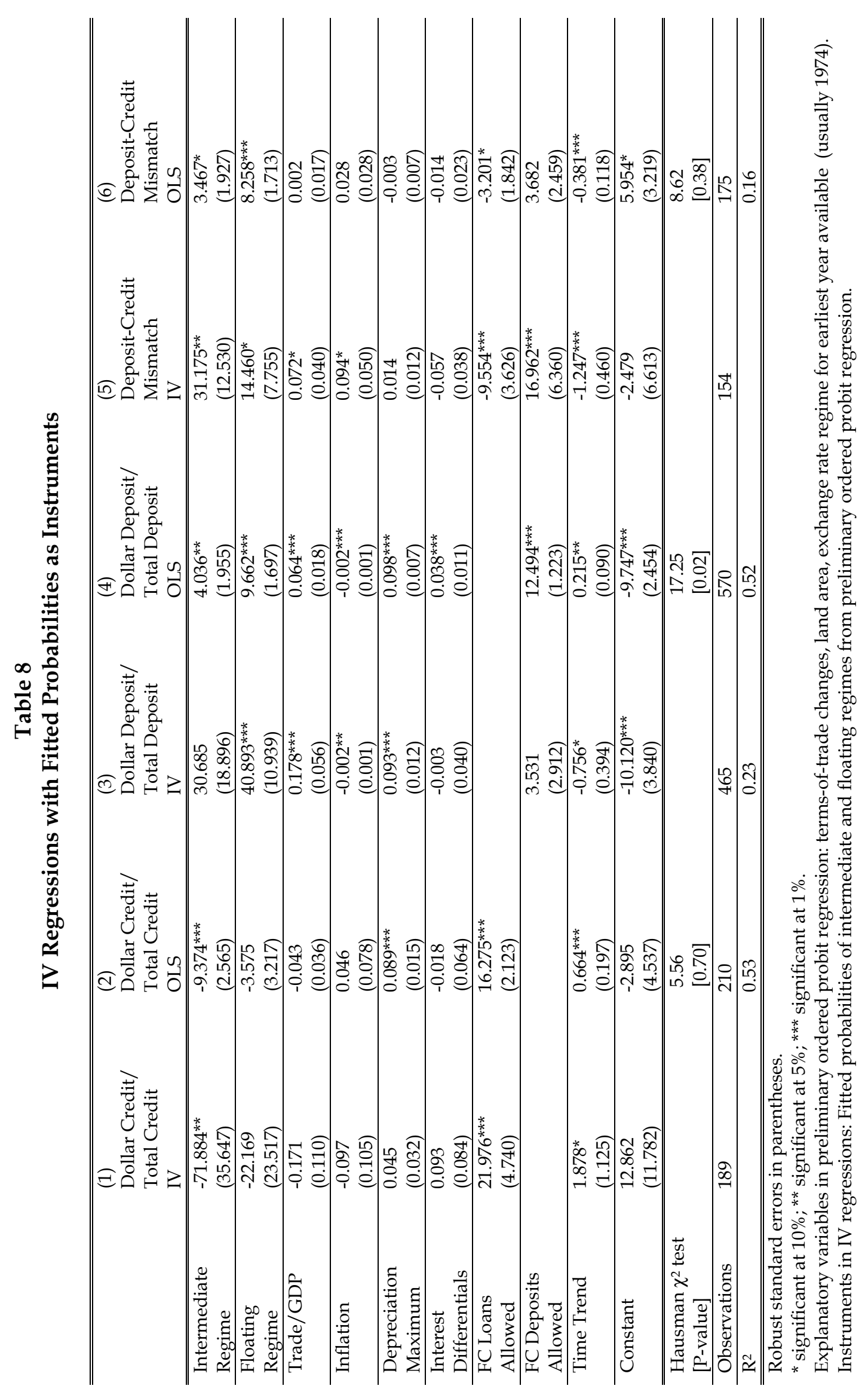

